\title{
"REDUÇÃO DO CAPITAL DE SOCIEDADE ANÔNIMA"
}

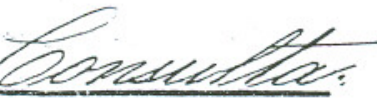

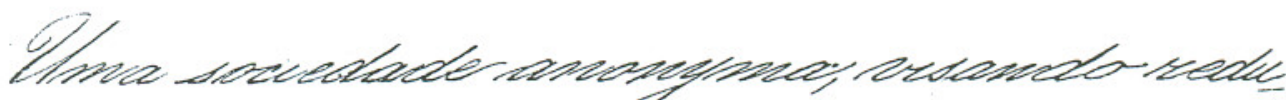

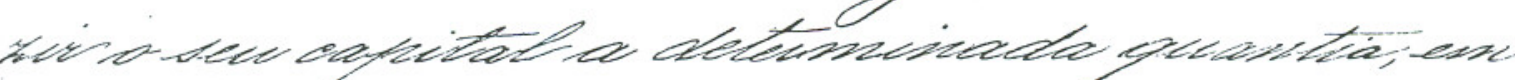

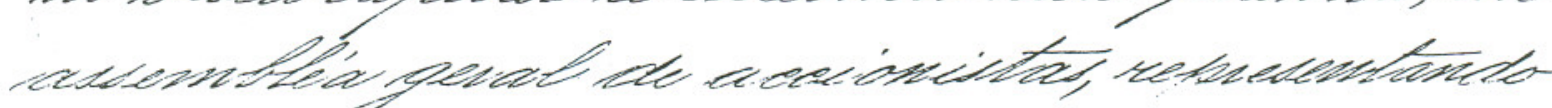

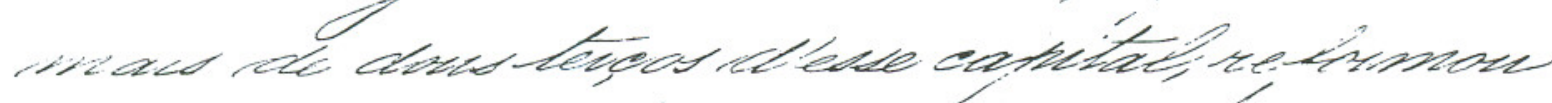

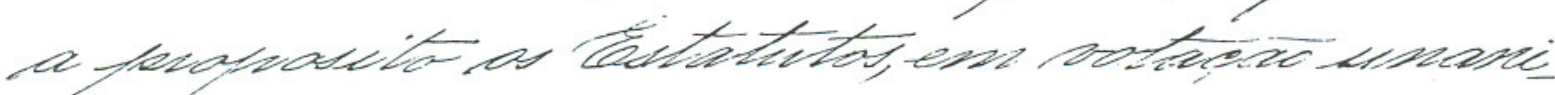

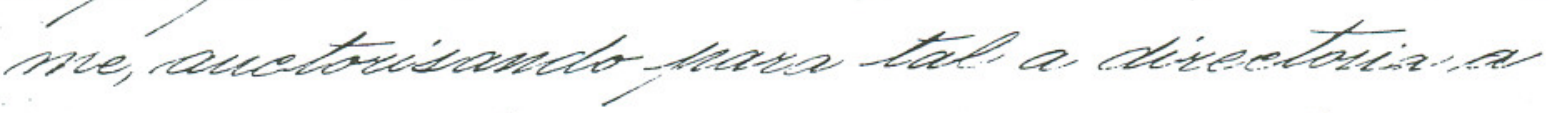

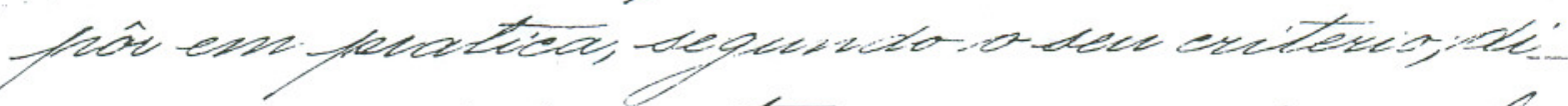

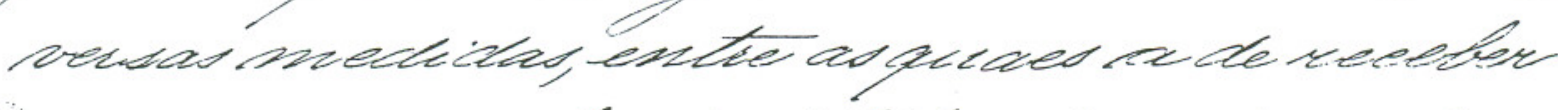

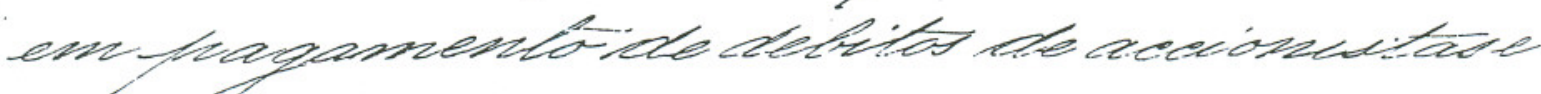

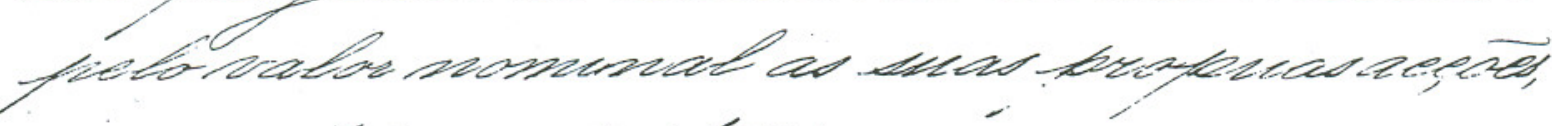

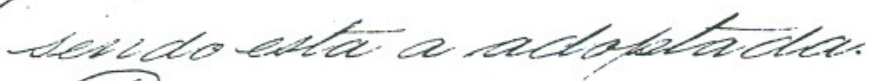

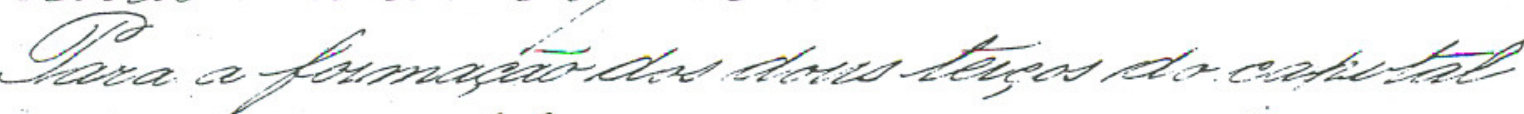

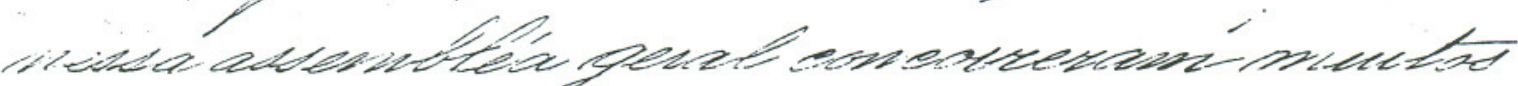

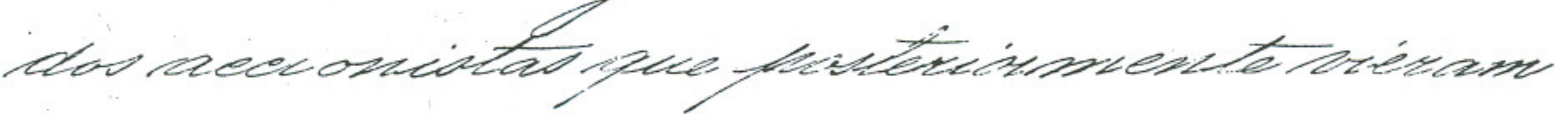

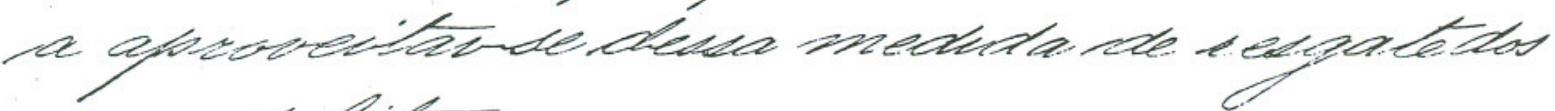
deus cuterias:

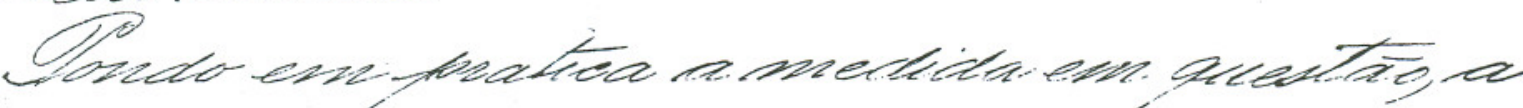

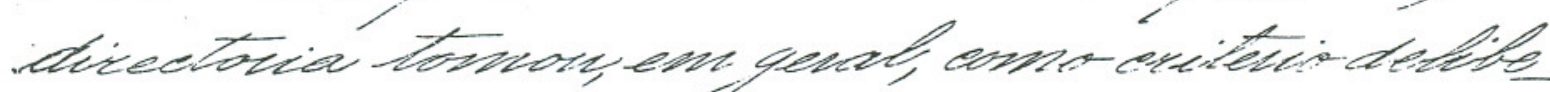

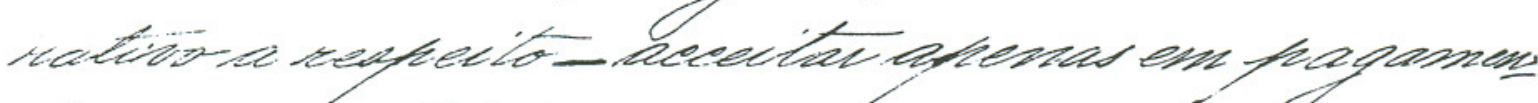

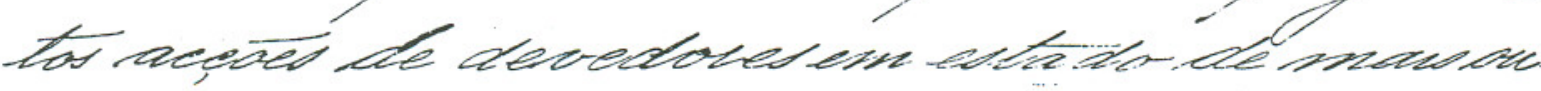

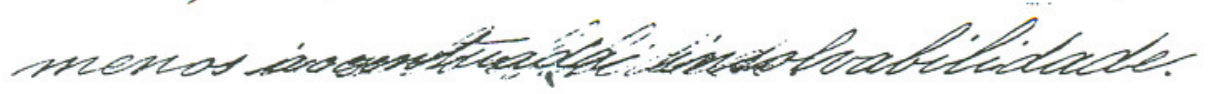


Herpenaterde.

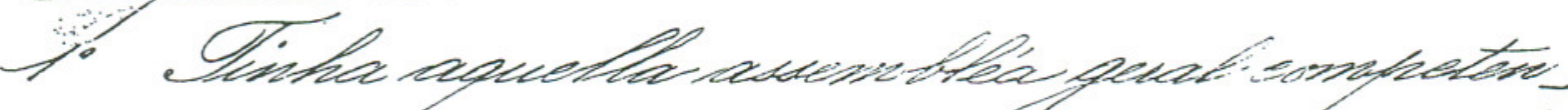

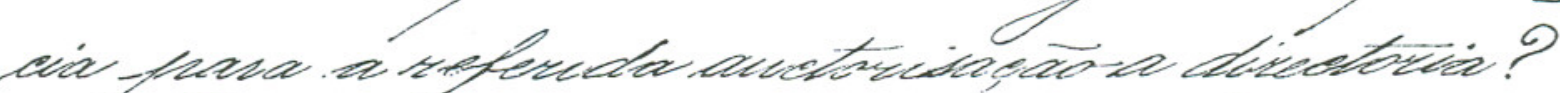

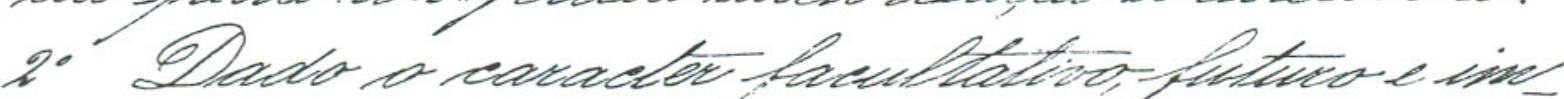

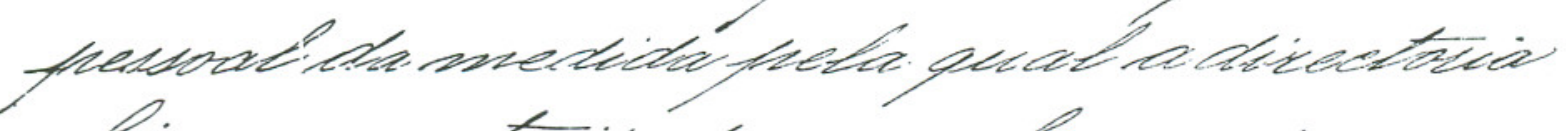

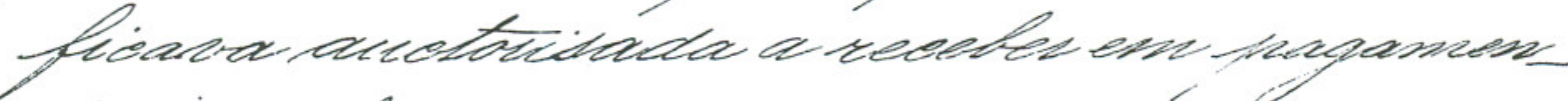

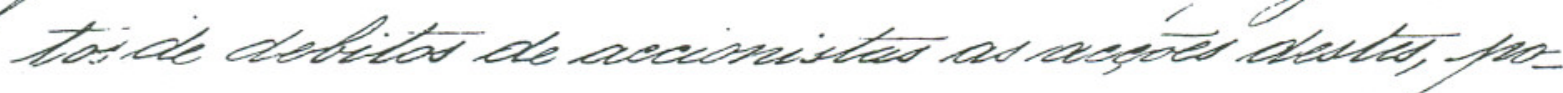

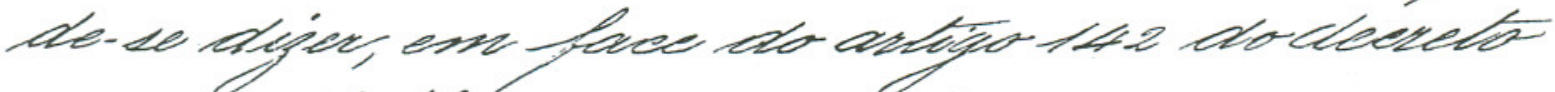

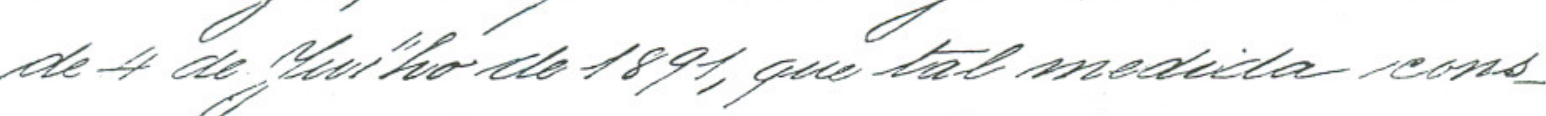

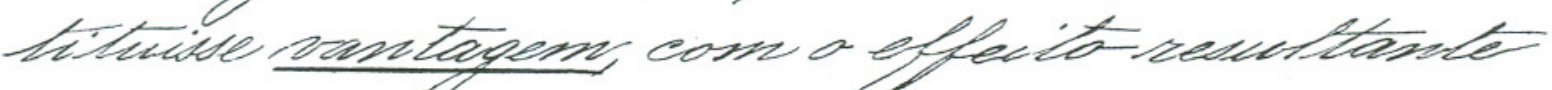

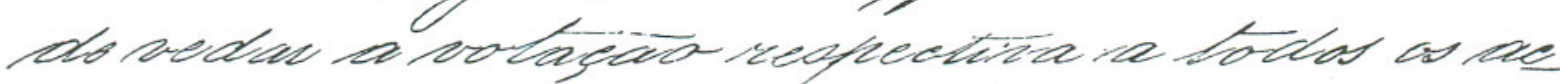

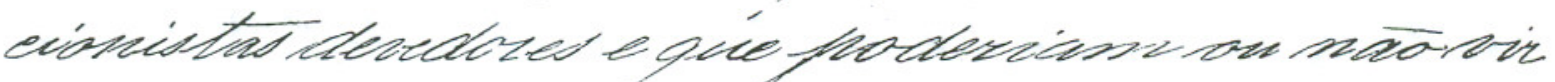
aproveitar-de della?

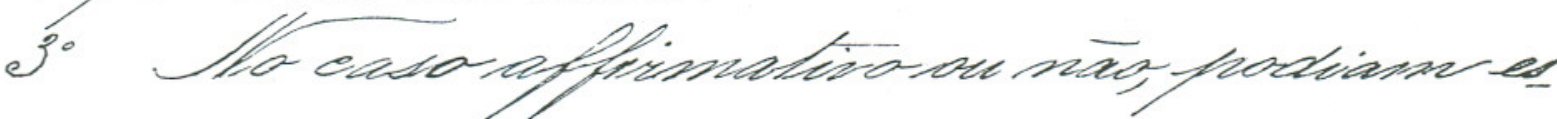

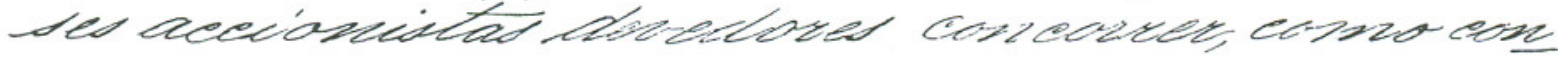

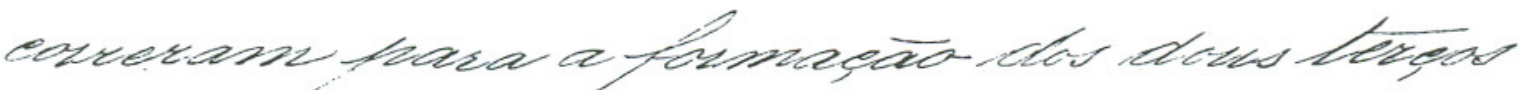

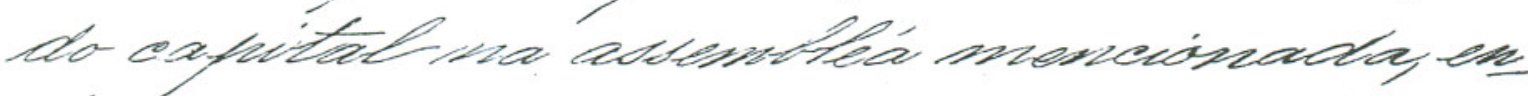

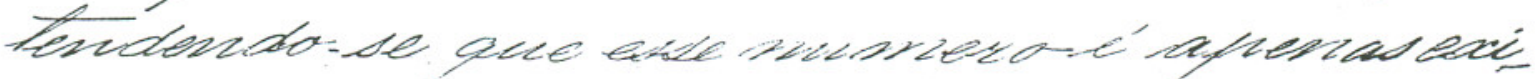

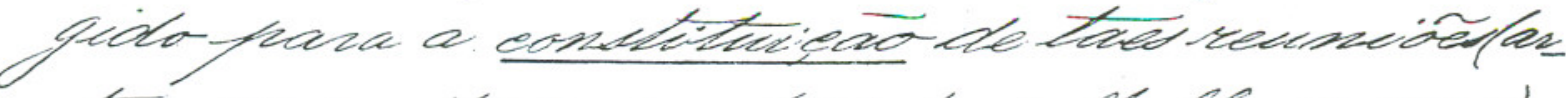

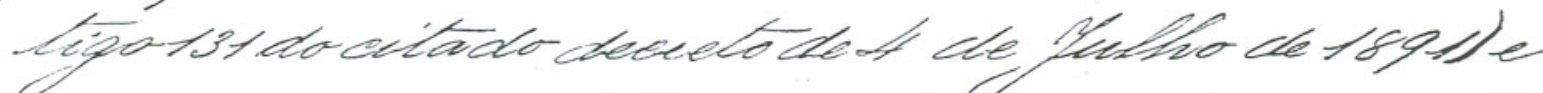

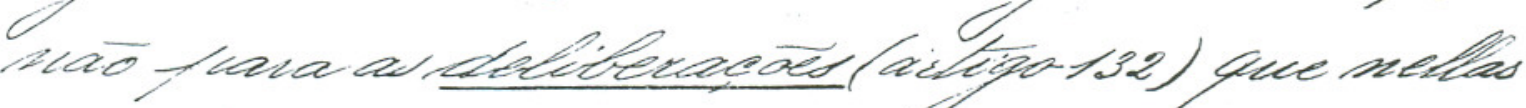

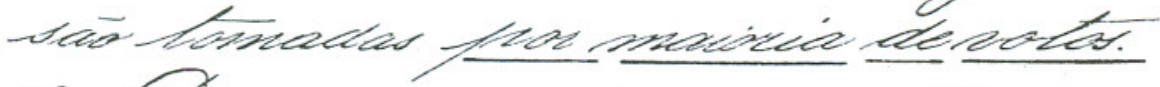

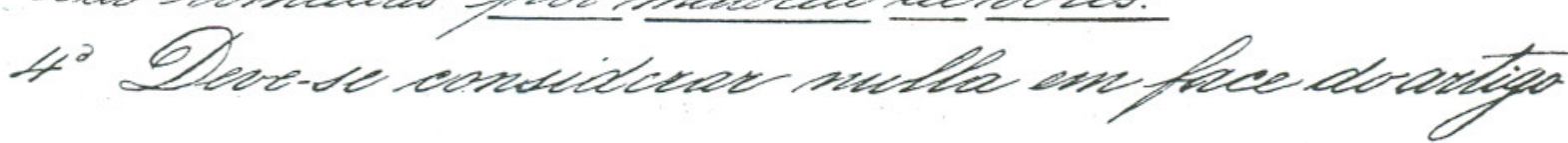




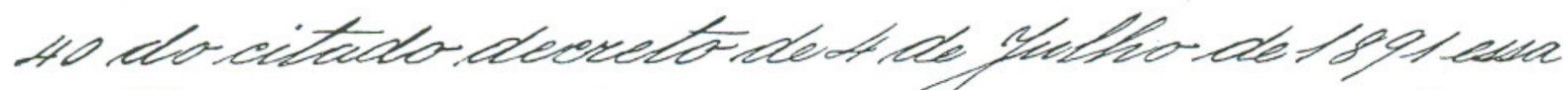

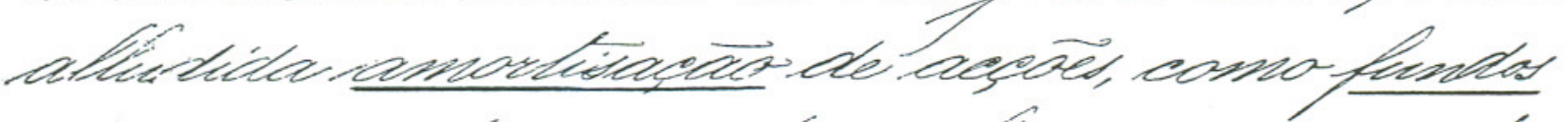

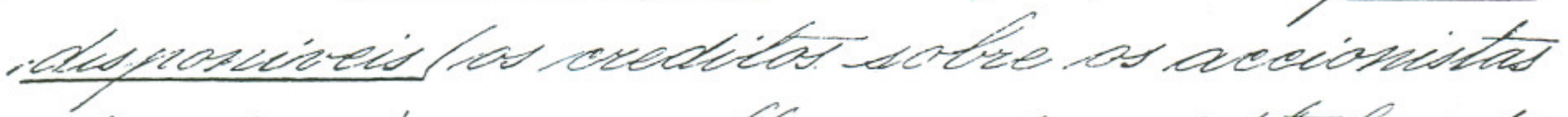

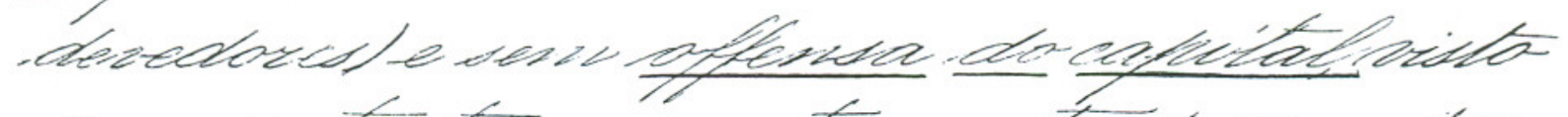

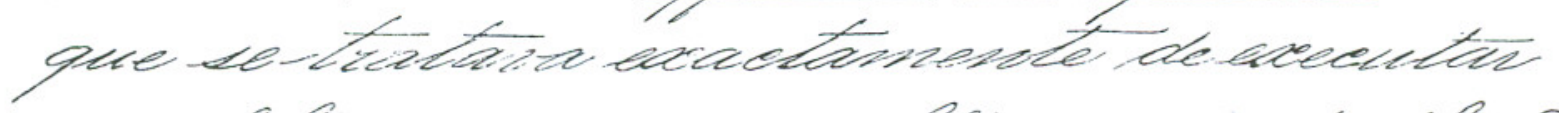

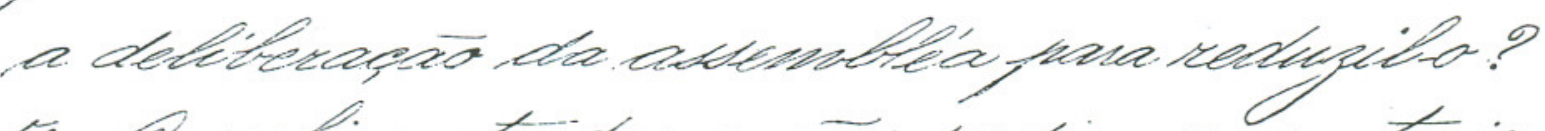

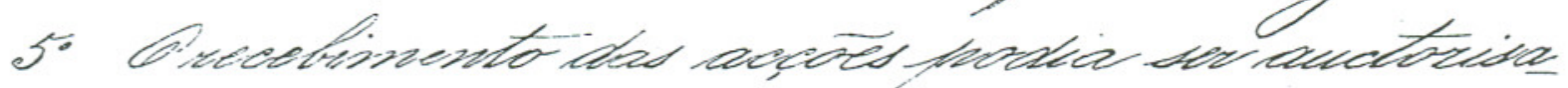

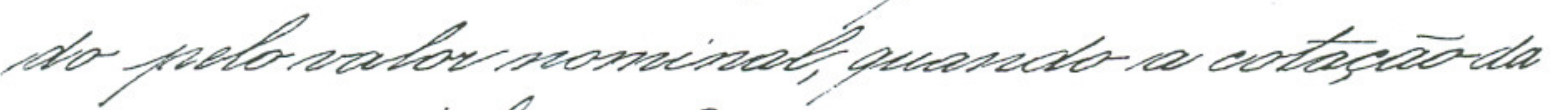
finaca eva inferion?

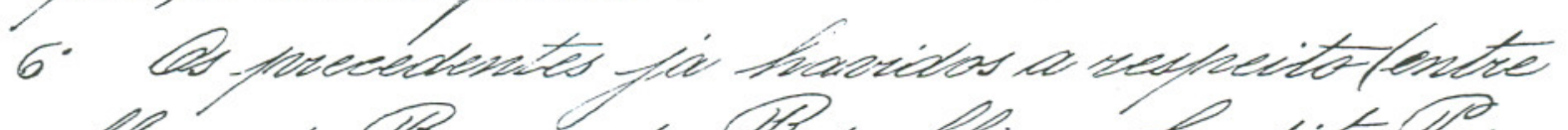

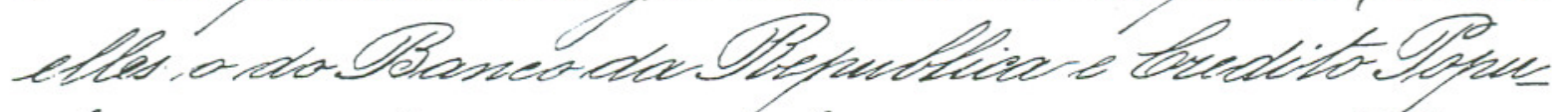

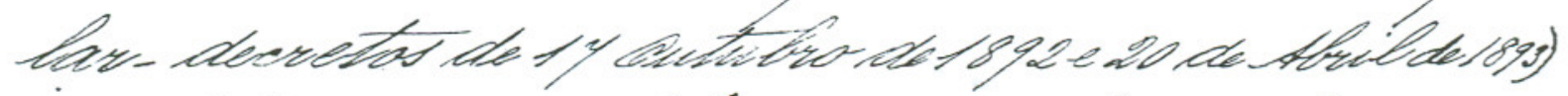

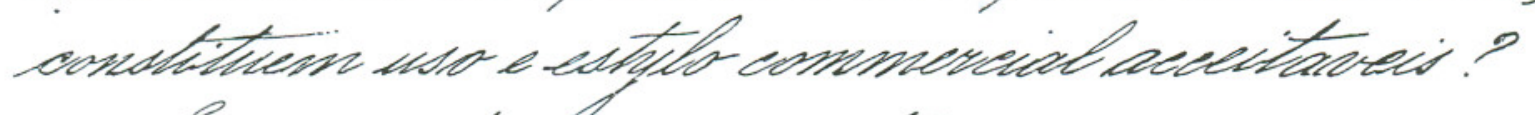

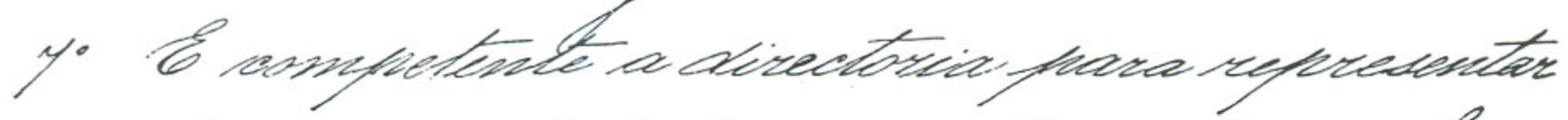
en fungo a dociedade, en aceico onde, cons funs

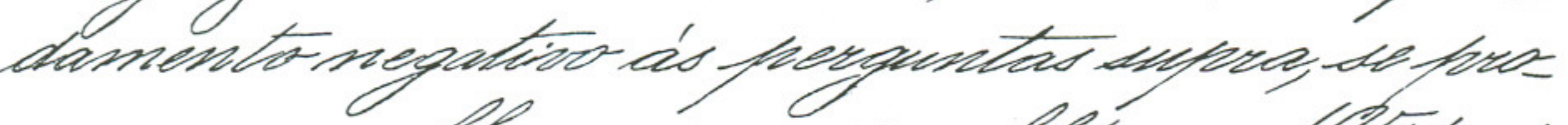

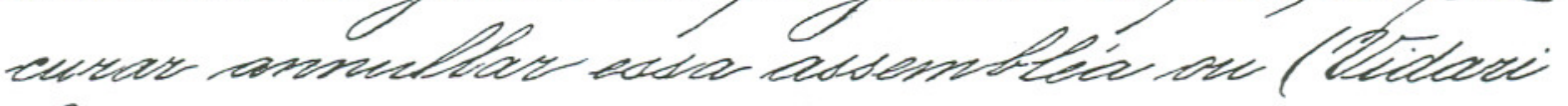

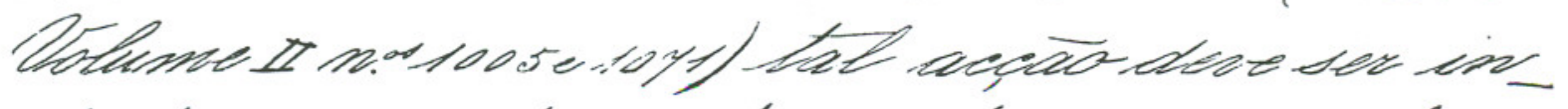

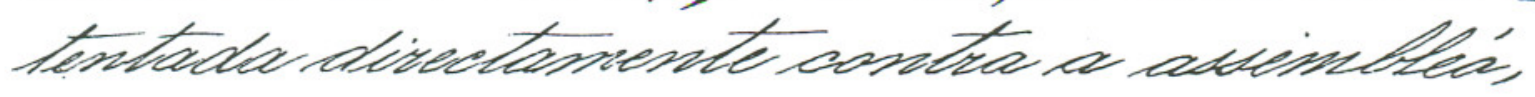

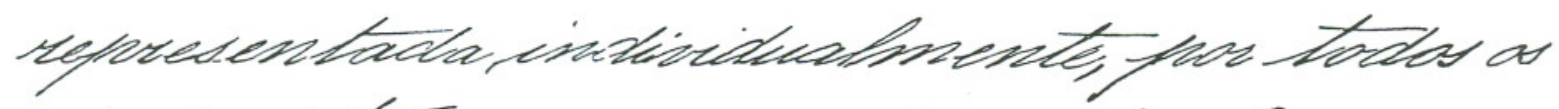
accionidtas, pue a compungevainer?

En cyumano- Ro, 3o R agorto, 1858- theng. 
F. Martín

14 ma da candelana sobrars 
- Pareer. -

$I \& I \mathrm{~V}$

Para altarar or estatutor, redijuinds o capital vosial, e' competernte a cipfermblea feral

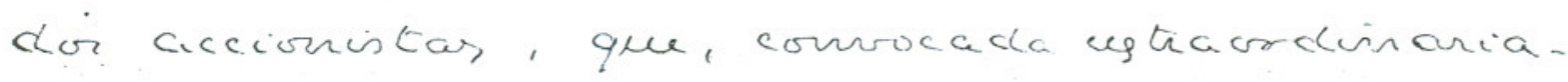
menste, te connpugen de tancor unernebror, gecors.

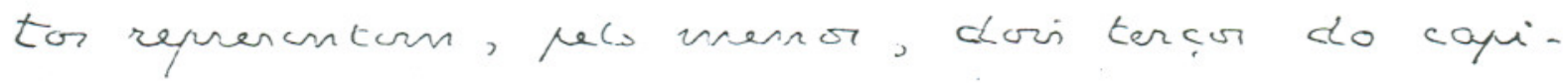
tal ( $8 n^{\circ} 3.150$, cle 1882 , art. 15, \$40; dear. n.8.821, do unesmo carrno, art. 55; clear. no/64, de 1890, are. 15, \$40; reg. no 434 , de 1891, are. 131.)

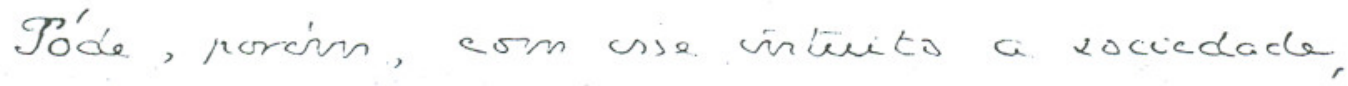
clas assumbleas

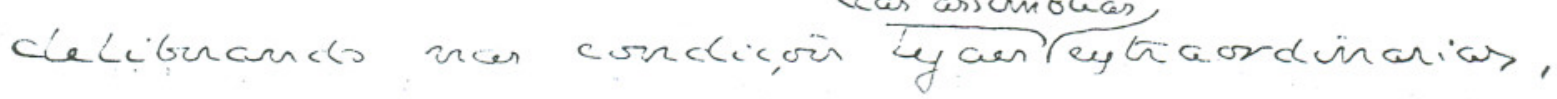
anctorigar a directoria a recear em pajarmento cle debitor de accisingitas, pelo sen valor norrirnal, as juoprias accoiñ 2

Pis a especie a a guestas vuncitacla no Mrimevio e quarto quention.

2' de overtiona que na corryutencia para fazer rechegi o copeital rocial ve inclue o podir 


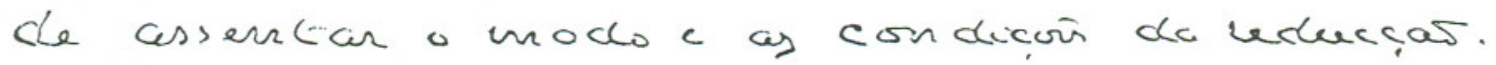

"Sorsque les statuts eutorsiont l'as.

vernblee géne'rale den actioninaires à decider

La rédenction dhe capetal social, on dit con-

siclérer que cete autoriation enstracine le porevoir de clécider le moch et len corditions de La récenction. \$

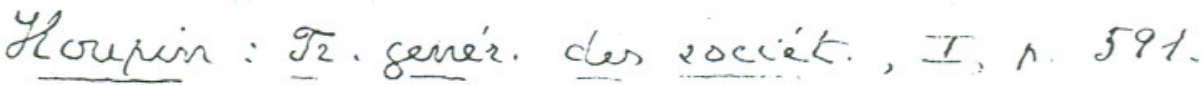

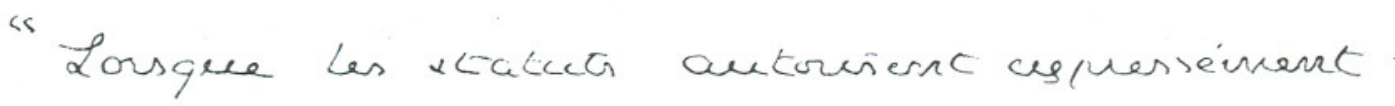

L'asfernbtée générale des aclionncuires à décider

La réduction dee capical vocial, ore coit corn.

siclérer que cette autsriation entravire le

pourroir de déternnowiner le unode et les corredi-

Lions de ta réderctions \$

$$
\text { Ibid., r. } 59.3 \text {. }
$$

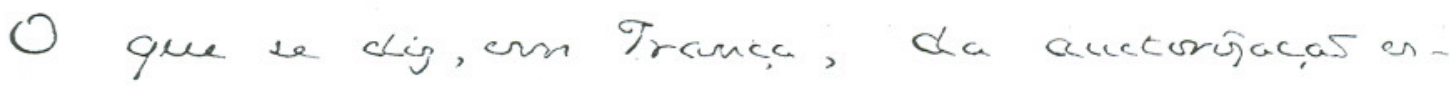

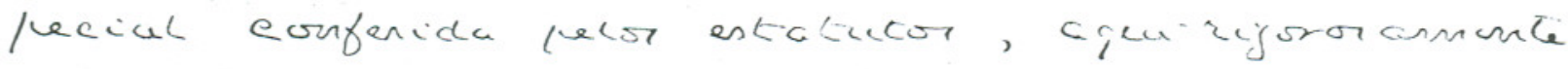

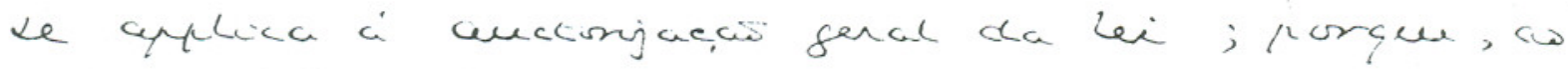
passo que for esta, entie noi, as asfermbléas cytraordi.

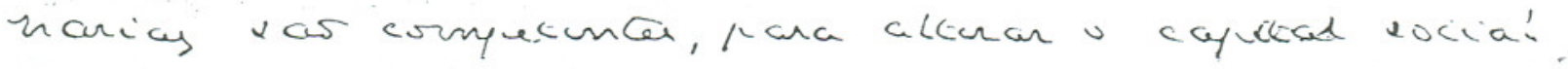




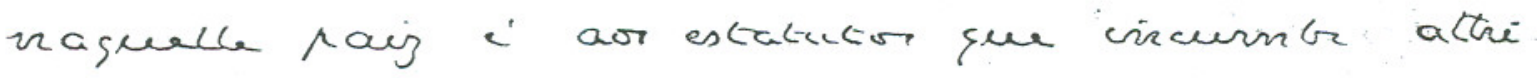

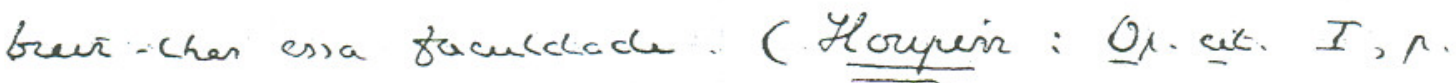

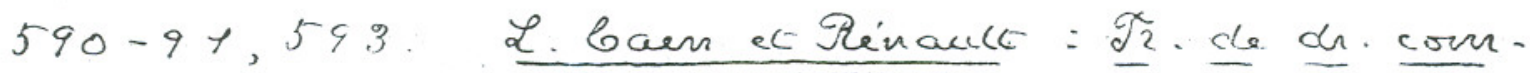
mene. II, $\mu .646,64 \%$. Varrasseur: Societés, I,. 99,80 Calcumanchei: Delle vociecà, TI, 1.118-2.

Do unesinio mock como, portanco, tho arbi-

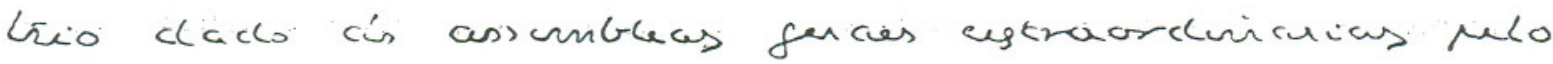

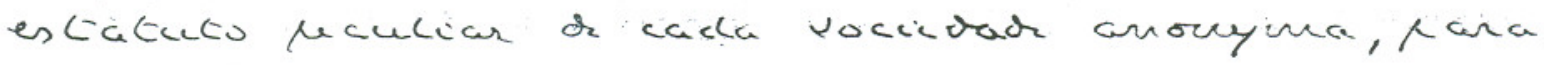
mochificar o capreal, yuso facto de sirclere o criterio

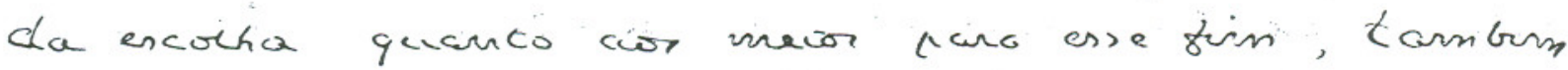
un a ciltribucicas geral que, a esse renpeico, then oucor.

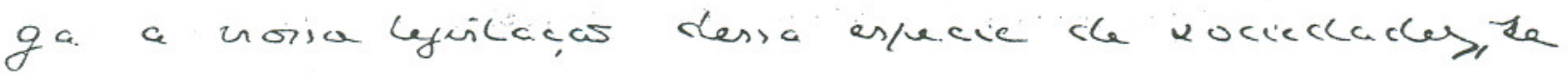
encerra "yio serre cdenteco rocker. "Euem guer or

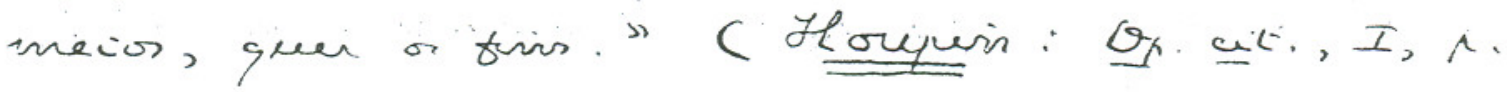
5.91$.

orecinfario 'e', porion, que rara a correcucas

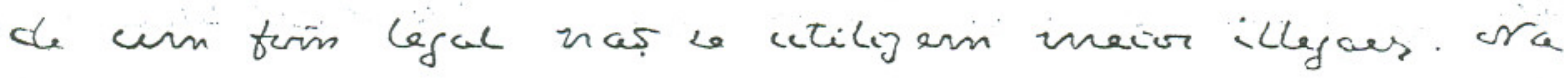

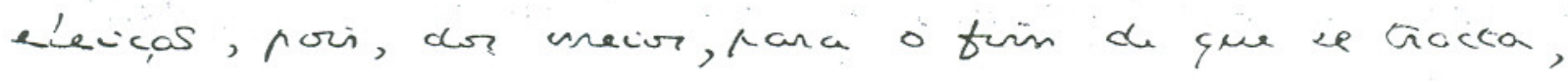

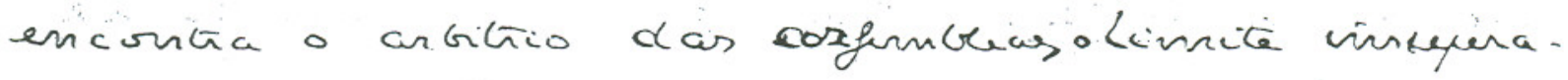
sul da lei. Sera contiario a ella o mario emprajacto 
wa hyp sthere?

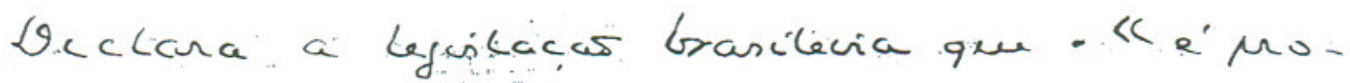

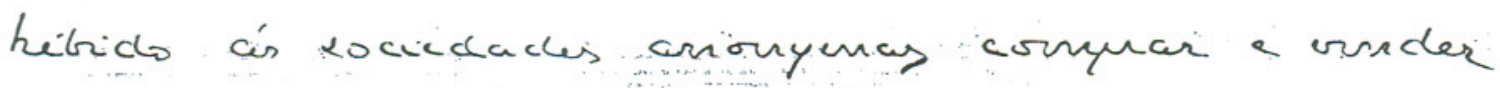
as Moquias acciós. D

Mlan accrencenta logs:

" orenta Mohiocas nas de comprehende a arnor.

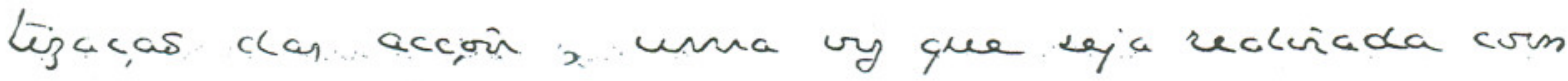
funnder chiponiveis e ene offerma do capital. "S.

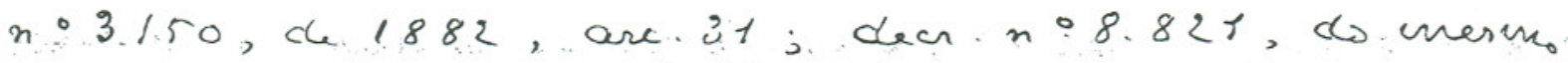
armo, art 20; dear: $n \cdot 164$, de 1890, art. 31 i reg. $n \circ 434$, de 1891 , anc. 40 )

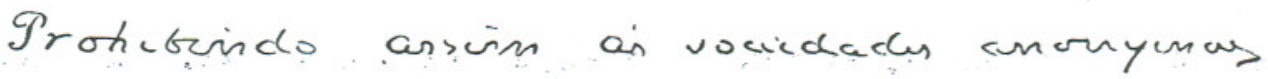

compuar e vonder an moprias accoons. (ansas cla. ra e' de ver viso" a espluessas "comprar (under"), - gue a la torr ens menta, foi urdar que vobre ellas

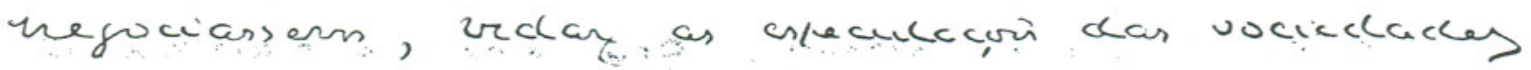

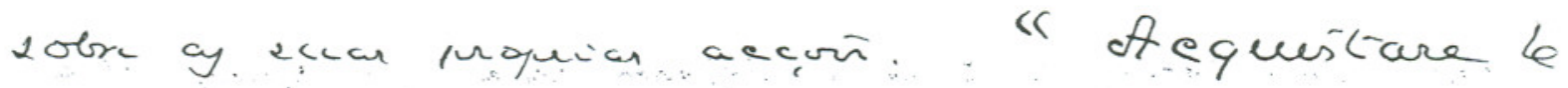
agioni vociali eri clemsur della vocietà". (xos Malarrar de Vidari) ruol cire, nè Miù nè ure no, che acgmitare decla roba mopuia, a far cre - 
dere ad una estongione di debito vociale, filtiyila del tulto; imperocché, Magan do il corresipteti. wo delle agioni, non si fa che postare il clebito Insomma i allegerire urna tarca, per agfravar L'altia Il quale tranello non prió arvere alio ¿coplo che di cinprimere alle agioni un movimento cinfarmavole diriabo, per far credere acl uma ricenca molto anvinata de enfe e ad una provperità economica che è faha del tulto. ¿ un modo per sori clure, di galuangjzare le società - mote, o vicine a morire; Le leggi clerono proibire affletamente quente inganni, quand'

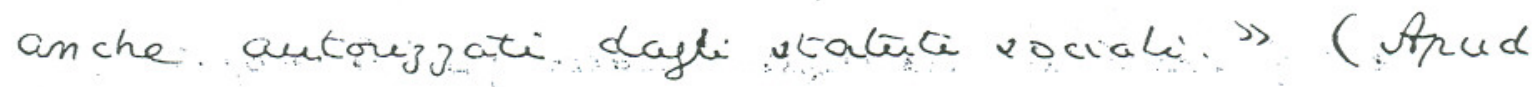
Calarnanchei, Welle vocietà e delle associag comm, $21,4.65,0.411)$

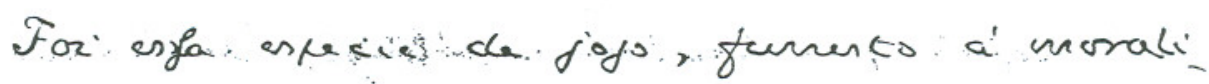

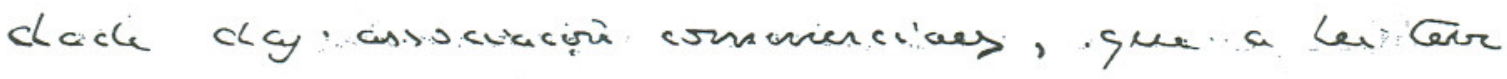

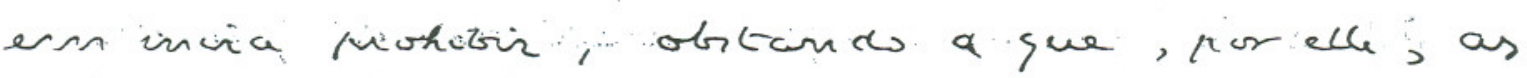

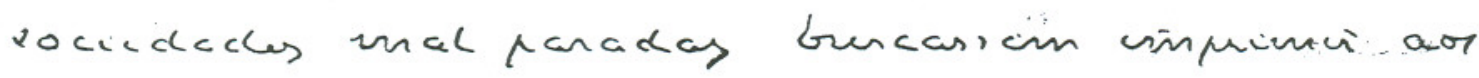

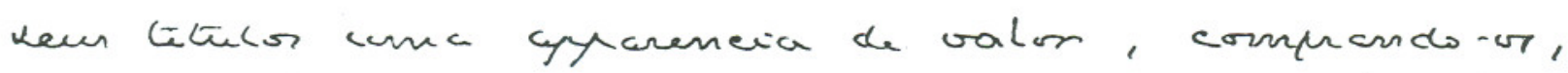




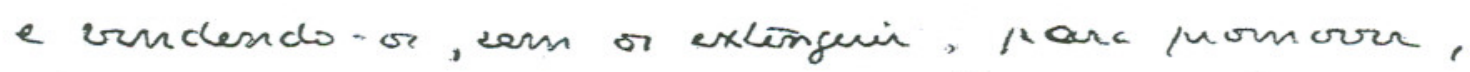

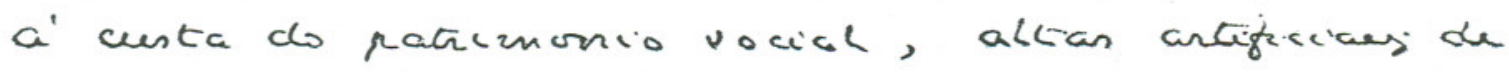
Lelar accion

rlas, for cifs merns, nas cabe a prokebe,as.

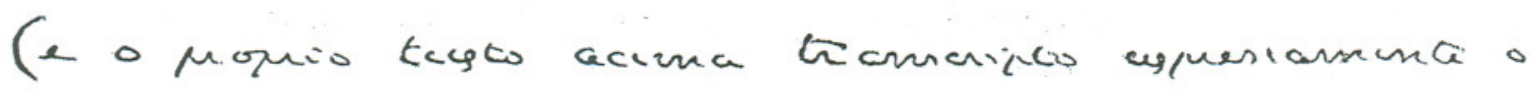

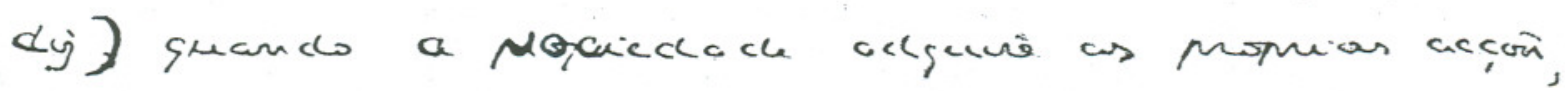

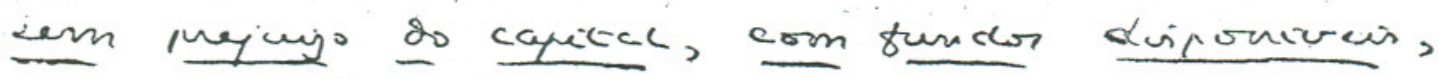
hara as ensortizar. cresfe caso o objecco da crmpua e' a reclencas do capital vocial, effeclieacla me. diante or receursor difurriveis da associaces.

"La prohibition ne "'apuigue point, quand la socke'te mocich à L'achar de Les propres actions en obourane hen conclitions et formalitén prencrites pour gue le caperial puife ithe rédunt. L'achat herait ctonc vala. be yi, La rédenction che capital e'tant auts-

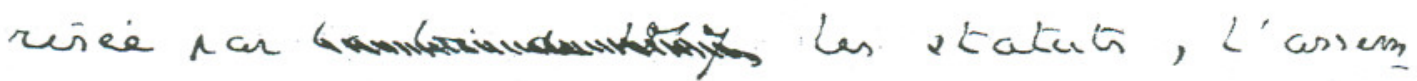
bleie fenérale constituée conforménment à l'art. 31 de la bor cle 188\%, arrait clécide' qué elle. ceura lien. 


$$
\frac{\text { Ryon-Caen et Rénault }}{659, n 9880=887}=\text { Traite', II, 1.65\%, }
$$

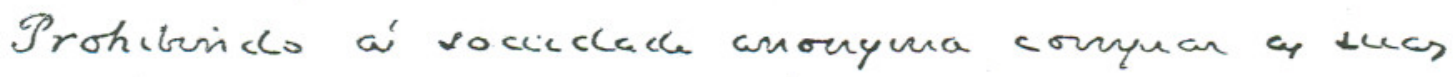

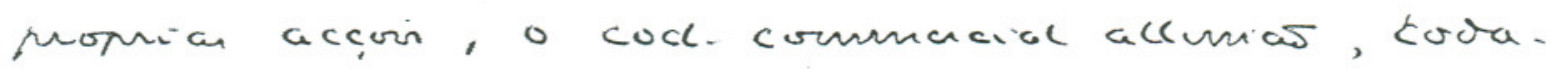

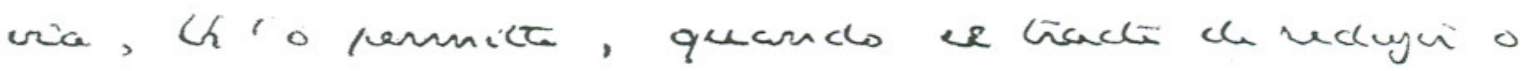
capital social, obrenradas as espigencias da les. (Art.

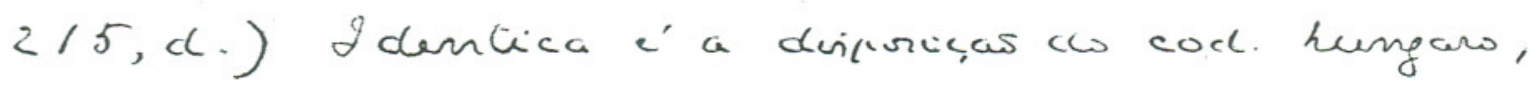

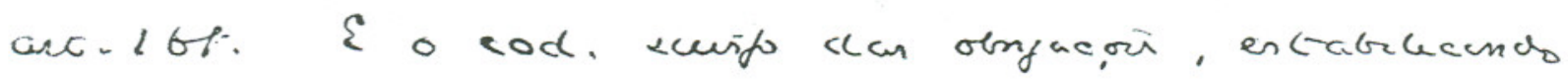

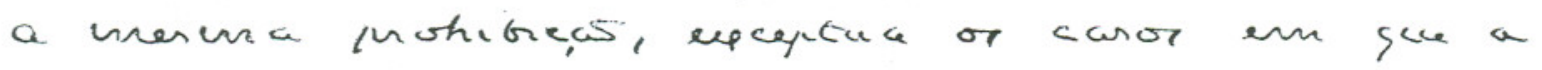
acgeniticas clas ciecoin "for a comsegenncia ch enfor

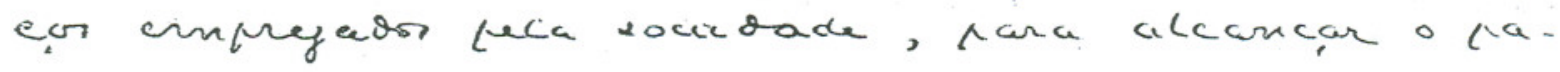

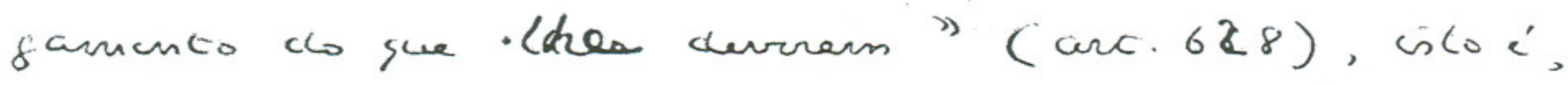

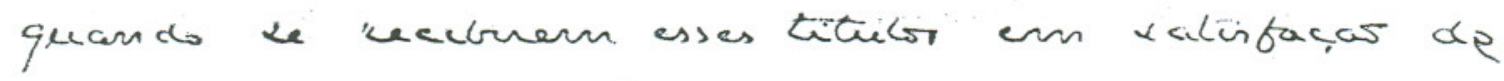

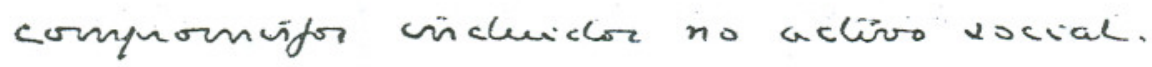

era enfecic an eccoin foram recubioas, afin She reckegui 0 caprial escial.

Mar le dentaleore, para on argeciein, o cafie-

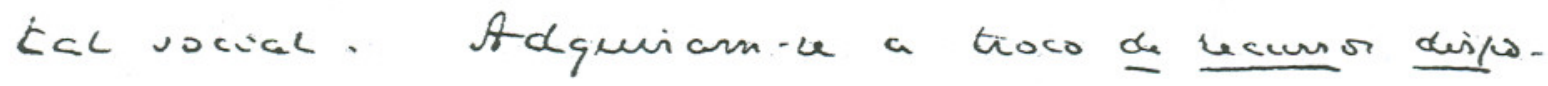

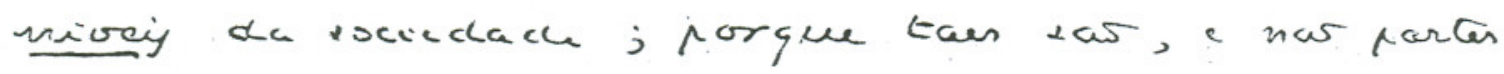
clo capuital vocial, on debitor action de una associagas. 


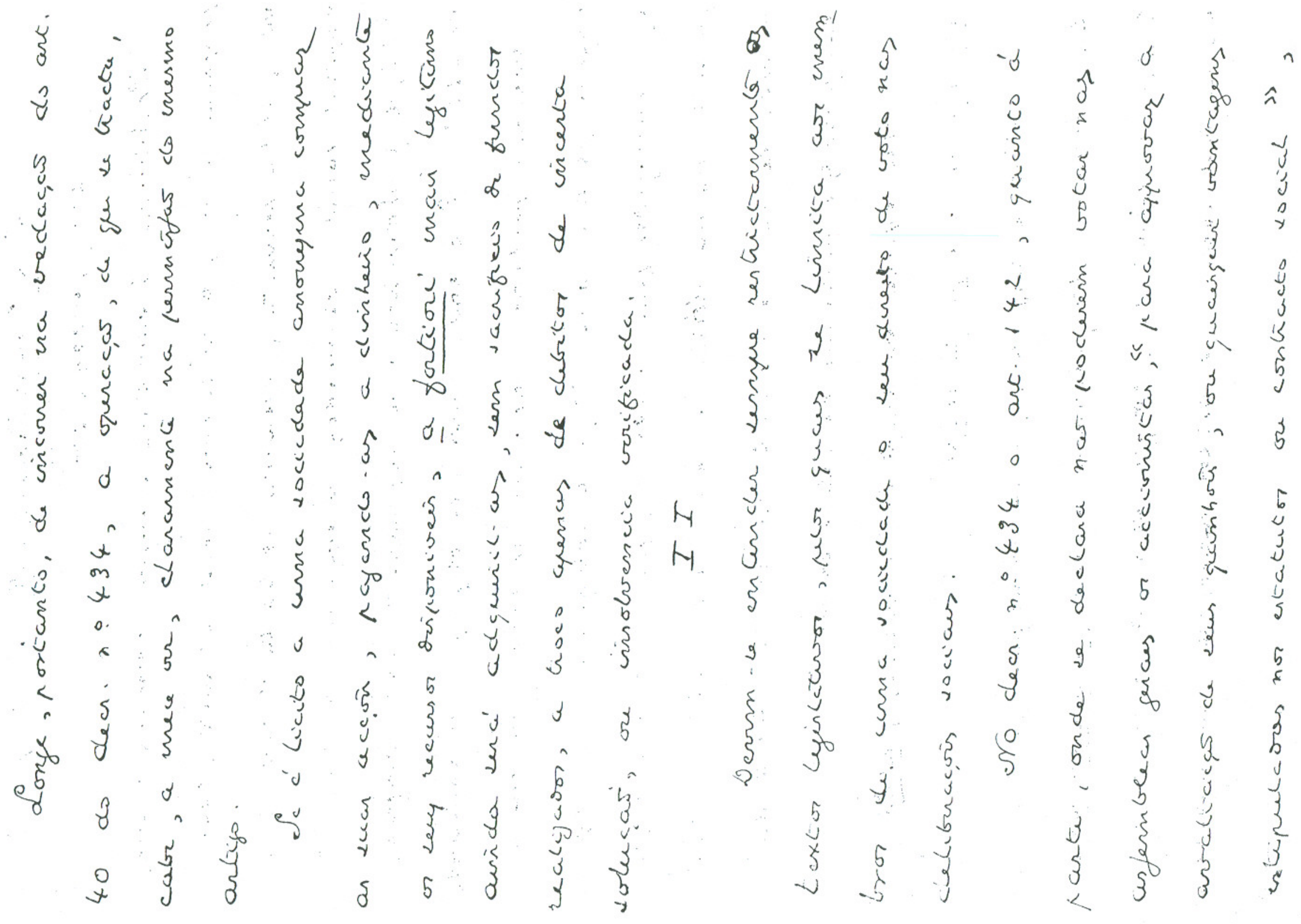


e'reprockecas da lei francega che 24 cle giul. de $186 \%$, arc. 40, onde, estatue : Les associer qui ont fait L'apur ore thipulé des avantages karticuliers tournes à L'apuécicition de

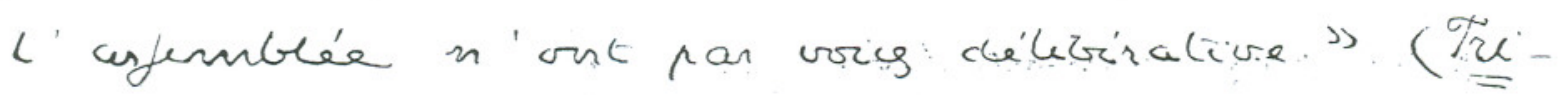
Hers: Coden traneacs, ed, de $1898, \ldots .628$ )

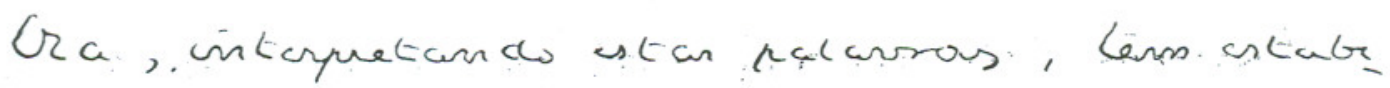

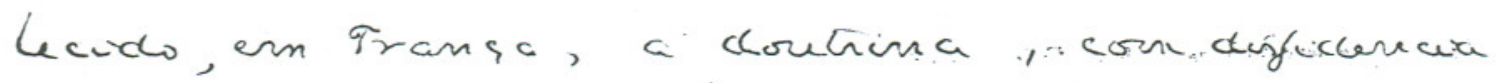
apenar a varrasfeure (joccietés, II, n:903, 1. 163-

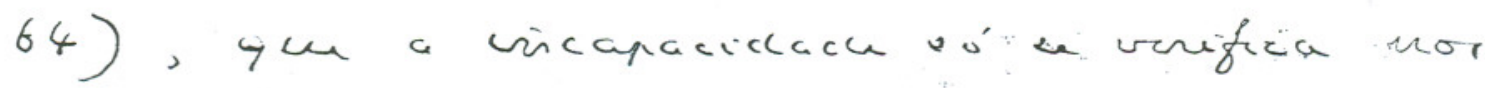
casor de "apura et arrantages", ore, na lingua-

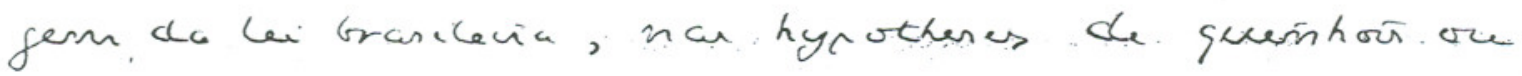
vantagens enterucactas nor entatutor, we no esntiacto

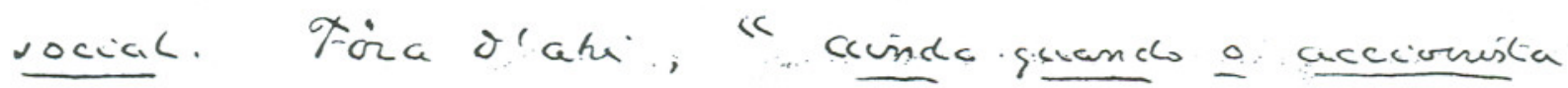
terntia cuteresse ressoal ha guentar ecubrectioa á

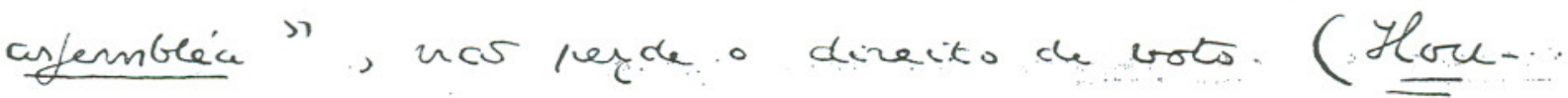
监, I, $1.566, n \circ 79 \%$ - L-baen et Rinauk: Iraité, II, $I .634, x \circ 846 \%$

oro vnermo tentics le exprime Enclencurne.

o panch comernencialitia allemas: 
"A collison entre o interesse esfecial do accionita e o siteresse coinmem ca assocekgos nat acamecion a obryaces de Le abiter clo ererutinio;

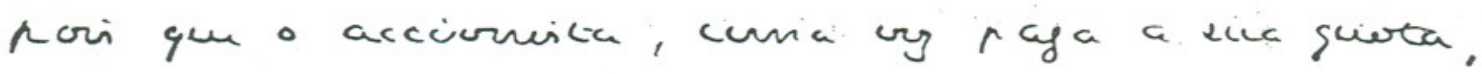
fica perfectamente liove para com a sociedacle,

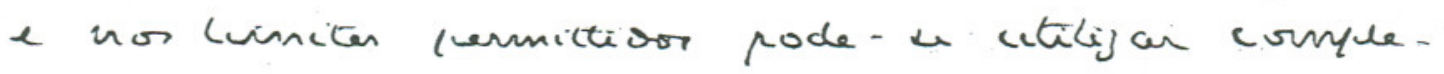

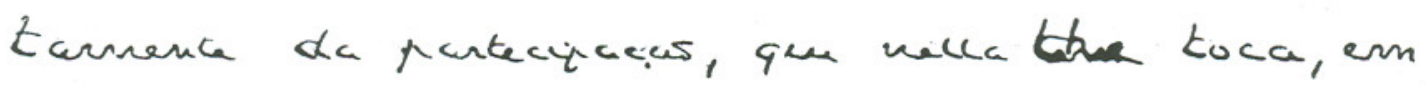

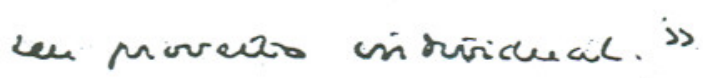

C Man di diritio consmere. Trad. ital.

$$
\text { v. I, }, .60 \%)
$$

Mar de tractionclo, portinnto, na enjecie dor earof taygativarnente enemeract no art 142 do dear $x$ : 434, cisto', che apuorar a cirraluacas de gruñtors

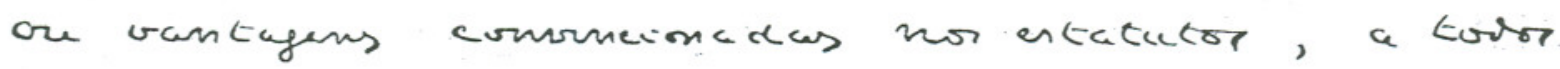
or arcionintas cabio o. divicto de veffragio. Só essa

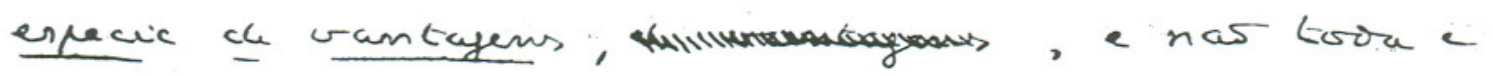

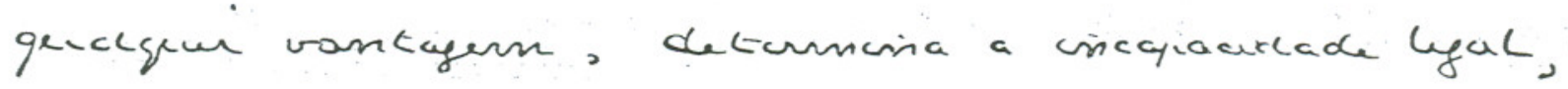

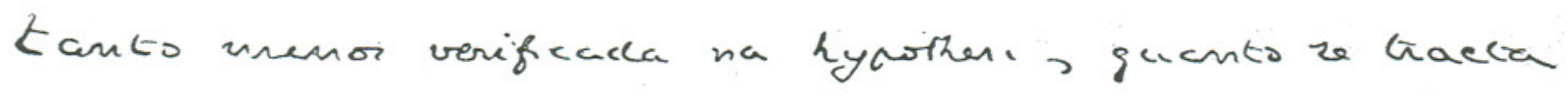

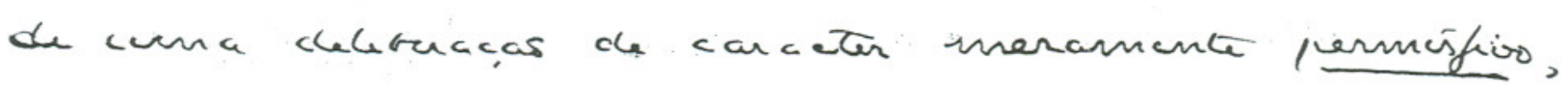
conpessoal a futero. 
TIT

Entre on reguisitor entableciods no art. 191

2 no art. 132 , o Moinecio rara a constituricas

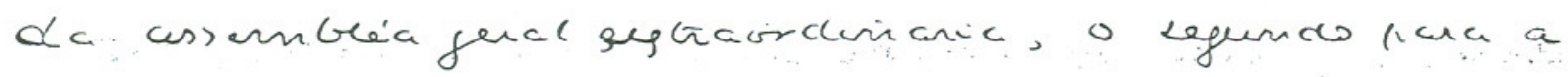

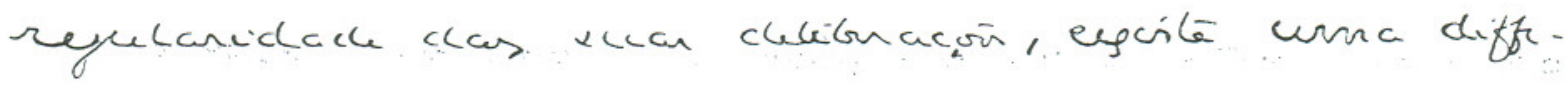
renca uncmiferta c Literal.

Ielo are. 131 , a assembeía geral

"carece, sara valiclarmence de constetecir,

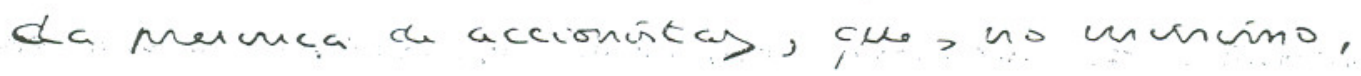
requeruntern ovis tercis do capital social. Ds

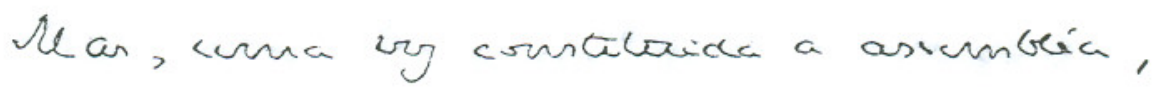

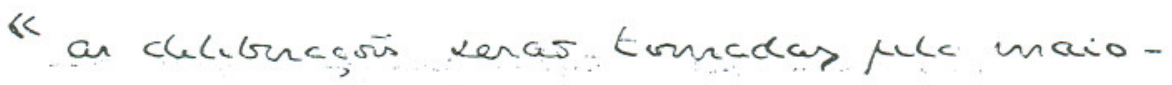
Ric Cos excior prenentes."

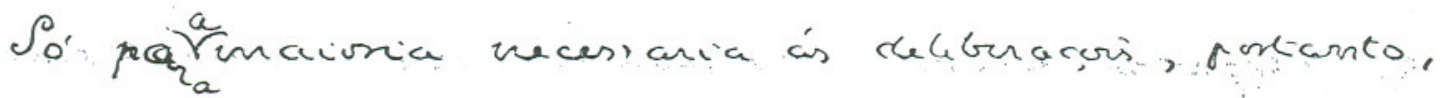
e' gue a ler conta or pocior. Mra uncuioria rara a corm-

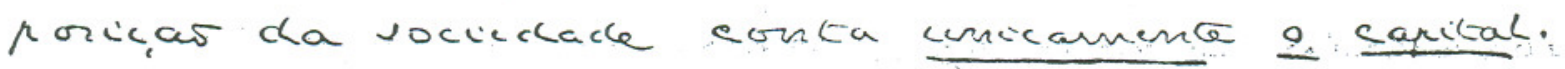

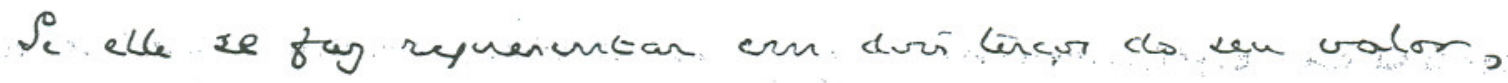

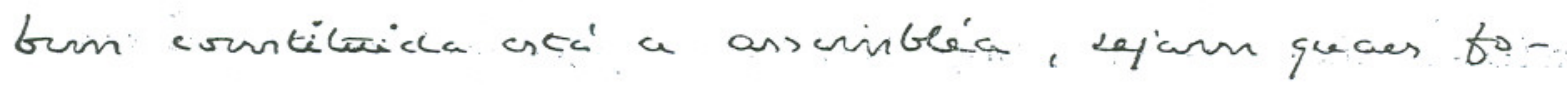

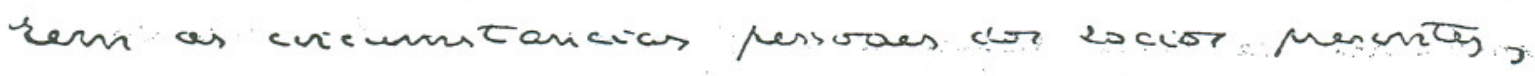

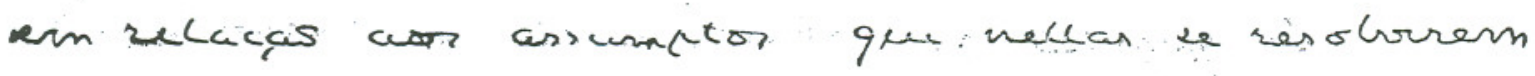


Toritarn vots? Oras Einharm voto no guentas? Pouco im

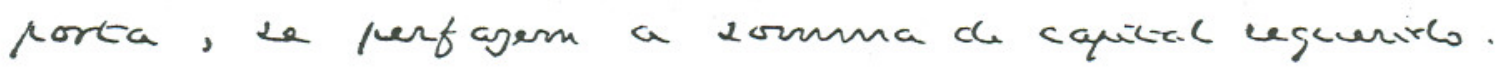

Responido, poir, as guencte ctfrimatioumente.

Atricla gacando of accionsentar, ch gue he tractas nas

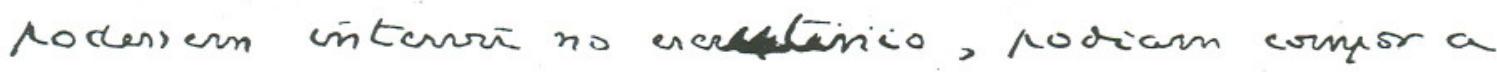
cessemblea. E, croms enta votou por unanimitad an orcubracion aroptatass, forsum, ore nas, calages de voto esses accionsitas, nat de nock regar que

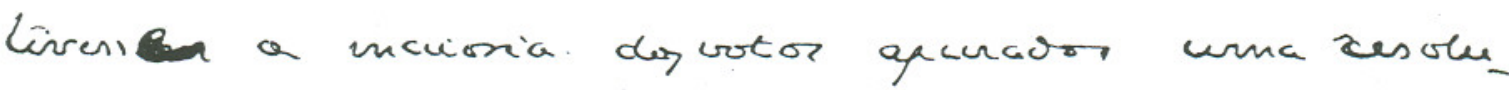
cas que or obtare todor.

V

No uso da cutribucicas, gen cher confere o dear n: 164, an 1890, art. 31 (reg.n:434, art.40),

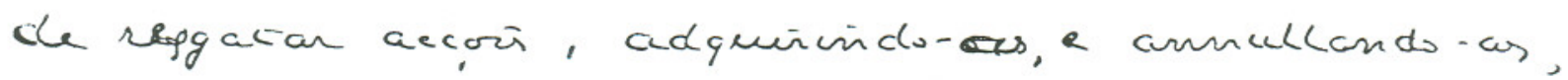
afurn de redengà o equital rocial, nat pockern as

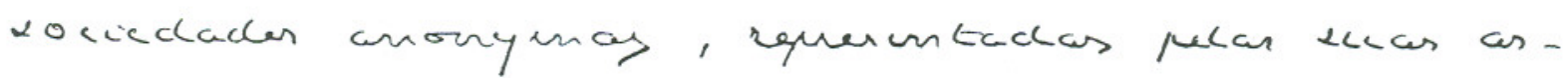

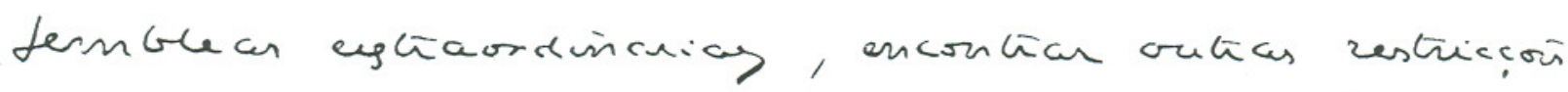

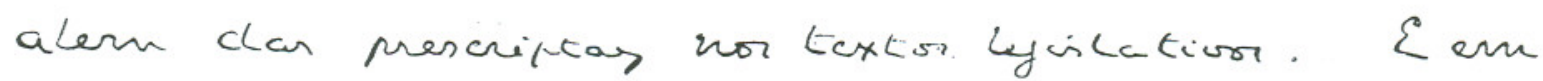
nentium se me clepara a figcuracla nente quenito.

of quentas me parece antes de convoniencia 
e unorabidade Mas nems unsa ners outa we parecern inturessadas no caso, clende que, abern de de nas biactar de compua no unencads, unas da acquinicas dan accoñ dor moginior socior, a tramnaceas nas foi uncur geu uma permuta de accoôs

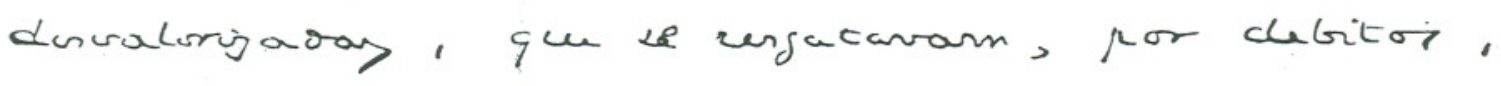

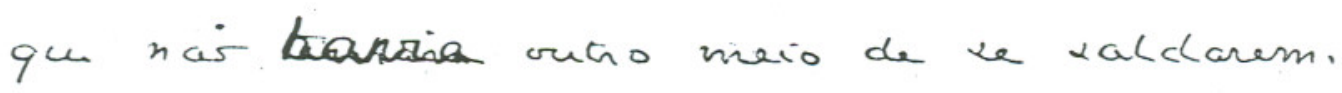

vI

Ia forse contrancia a'ler a operaces de reclegier o capital docial, recothendo e concellando accoin, a adotecas clesse uneio kara a reductas do do Ranco cha Republica no dear.n: $1.66 \%$, the If de dyunbro de 1892, art. 20 , e rara a do to Manco Heyrothearis do Brasil, no clear.n:1.361, che 20 de abrit de 893 , are. 5: $\$ 10$, ceriala illegalis, nuclor or seus effertor.

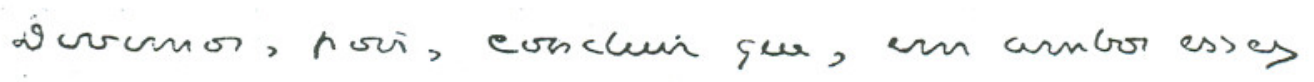
actor, nar for a pocker expentiro outa covia gue ax Mlicar a levi, ammeincls no uso, por associacoiñ ano-

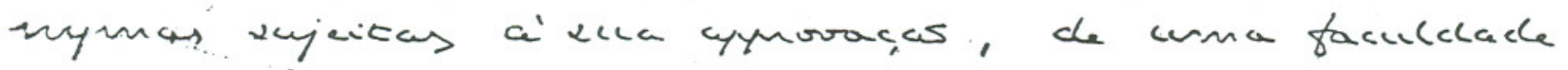


legal.

2, assun ontendidor, nas une parea contestarel

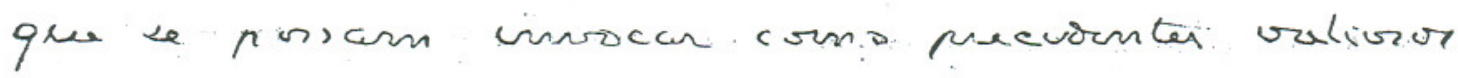

VII

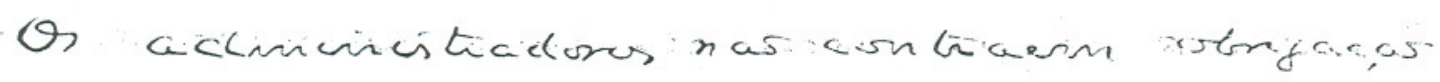

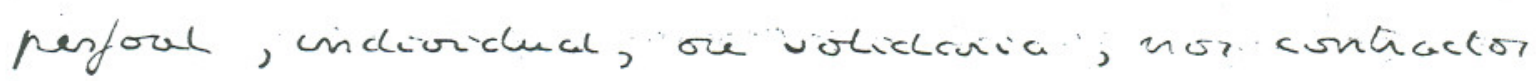

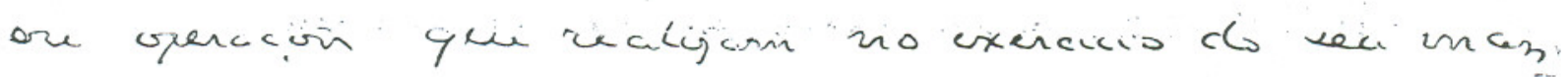
dato (bean n:164 ch 1890, urt.10, \$20. bean 0434 , che 891 , are. 108 .)

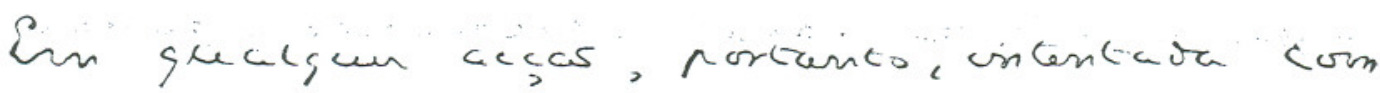

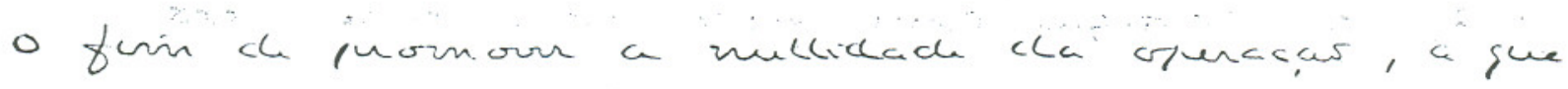

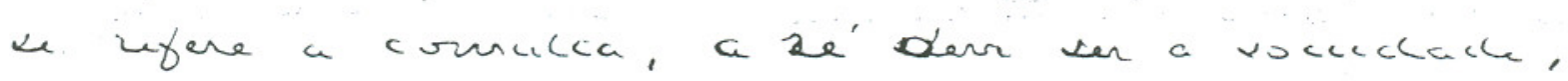

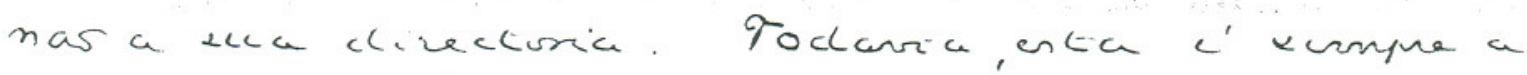

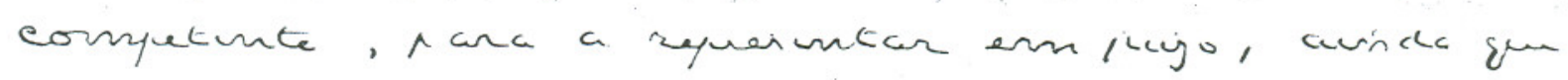

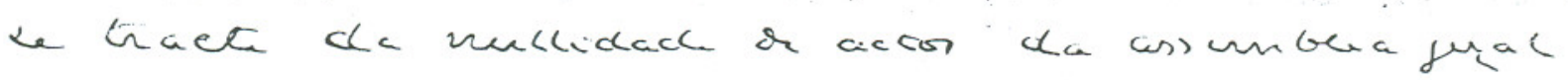
por contranios á Li (Noori: Societá anorima, v. I, n:322, 323 e kegs, especialunante n: 331,4 334$.

Rio, 30 che yoto, 1858. Rey Bantors 
I

A assembléa geral de accionistas de uma compantia anonyma, que estiverem represen kados pelo mem $2 / 3$ do capital social, e'com petente para reformar on hikatutos e, portanto, piara resolver sobre a reduciat do mesmo capi tal.

Naó pode, forem, para esse Aim - ankorisar pne ne jam recelidas as proprias aciós da Compantia en pagamento de dividas den accionistas; por gronto a darac in solutum equivale a'com pra e venda e an assuciagios anomymas éve dada a acgmixicat de suas aciver, salvo para amortisal-as e contanto gue a acquisi rai he faca com fiundo dispomivei, e nem offersa do -capital.

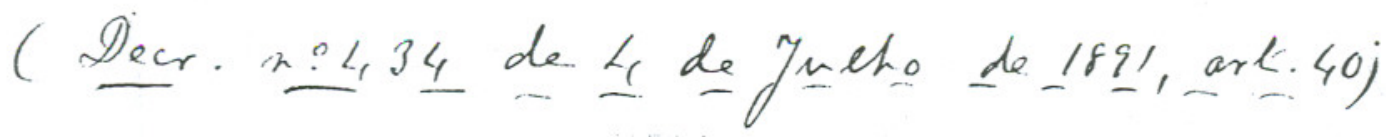
A eska razaó peremptoria, accrescem, para ainda mais accientuar a illegalidade de similhantz antorisaiat, duas comideragur, a saber:

a) impirta ella "ipiso facto dar as acsors un valor de occasciat, e jue chamarei Aicticio, o que e'mamifertamente contrario ao pensamen Ko da le suandu, wo cutadu art 40 du Decr. 
434, protilio a cumpra de acgoes', por ontro maio e para fim diverno: dos gue ahi mencio na;

l) importa mais, - no caso de nar estar reali sado o valor integral das accoes, dispensar "s acciorsistas do onus gue contrathiram as subcre vel-as, on ao -compral-as, -isko $e^{\prime}$, - realisar. repectivo valor nominal, esto en prejuizo da sociedade, e, o gue mais $e^{\prime}$, de Kerceiron gue sejan sem credores.

A reduciar do capital, mediante tal processo, e', pois, uma illegalidade, e, em certos -cason, participara' de frande, e ate' de crime.

(leod. Genal $=\operatorname{ark} \cdot 340$ n:10)

Anim, respondo pela negativa av lipres: ko

II

Indulitavelmente, conferier a' Direckoria de una associaçat anonyma antorisar,a $\bar{\sigma}, \operatorname{comos} a$ de gne ne Krata, e'ufferecer ars accionistas vantagen importante, na precion termos do art. 14:2 do Dear. 434.

On pagamentos mercantis fazem-ne em moéda 
mekalica on corrente. (lood loomm al arti.43129. $p ?$ ).

Attribuir, portanto; a un tiknlo de credito mobiliario e de valor instarel, gual uma acsao de comprantia, o poder de solver dividas, é egmiparal -o a' moe'da, o gue redunda em favor -comiderabilinsimo.

bomegnimteras, té, on acciomistas nat podian tomar parte em deliberacion a esse respeito.

(bit. Decr. art. 142)

III

A responta a este suesito esta' em perke prevemida na precedente; e accrescentare:

- 10. Zne a representacar do $2 / 3$ do -capital exajgido pelo art. 131 do Dear. 434 fognene neces naria somente para roustikmis, of da asnemble'a

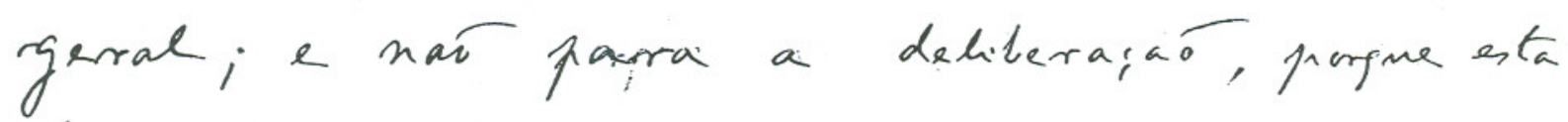
depende ipenas de voko da maioria des accí nistas presenter;

-2: Zne, na especie da comulta, porem, tal maioria nat pochia verificar-ne, visto jue, como ficon dito, estaram a accionistas izhibidon de nentor. 
IV

Iim; é nulla a antorisacaó de que se trata.

V

hitá igualmente prevemida a resporta: as as çust nat podiam ger recelidan em pagamento., nem pelo valor da rotaiá e muita menon pelo nominal.

VI

Naú; on precedenter Lavidos naó canstituem estylo commercial acaitarel. Ao contrario, n Decr. de 17 de Ontutro de 1892 e 20 de Atrie de 1893 ( que aliás excederam as at tridmicos do Toder sue $n$ promulgon) longe de atonarem tal pratica, confirman ser ella irregular e ná permitida, pus derogaran k. legislará vigente.

VII

Deve a aceár per prponta a' Directoria, sue e! a representante legal da sociedade em juizo a fo'ra delle. (- tit Decr art 101)

A upimai de Vidari, citada na comulta, 
apaia-u na legislasaó italiana gue diver ge da trazileira.

Qniv de Ja

de Agnto de 18 \&8

O. a Ounbrato.

$2 y \cdot$

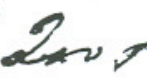

COMENTÁRIO

1 - INTRODUÇÃO - RAZÃO DO TRABALHO

RUY BARBOSA e AFFONSO CELSO DE ASSIS FIGUEIREDO, O VISCONDE DE OURO PRÊTO, entre inúmeros juristas de nomeada do início do século, premidos certamente por circunstâncias fácticas e legais então atuantes, expenderam pareceres sôbre o assunto que ora nos ocupa. São pareceres que não foram superados no tempo, por seu brilhantismo, integrando hoje a doutrina de qualquer estudo sôbre a espécie. Constituem, por isso, verdadeiros documentos antológicos do Direito Comercial.

O prof. Euclides de Mesquita, Livre Docente de Direito Civil desta Faculdade, numa demonstração de alto espírito universitário, revelador de um propósito nobilitante, qual seja o aprimoramento da cultura jurídica, cedeu a esta Casa os originais dos pareceres aludidos, para sua publicação, por invulgares que são.

Assim, a título de apresentação ousamos discorrer a respeito do tema, destacando alguns aspectos da então controvertida questão e as soluções que hoje the são indicadas.

Longe estêve de nós, na elabaração dêste estudo, abordar exaustivamente $\circ$ assunto, uma vez que não comporta em nossos 
dias indagação maior, pois solucionado está em definitivo por norma legal.

Apenas, como dissemos, através de uma análise perfunctória, nosso objetivo foi o de ilustrar a publicação daqueles documentos $\epsilon$ dar uma breve notícia sôbre o tema debatido.

Vale, antes da abordagem da matéria, uma observação assaz interessante. Nos dois pareceres em aprêço, como se pode verificar com facilidade, acham-se lançados, em seguida a sua conclusão, os valôres fixados por seus autores a título de honorários. Não se pode afirmar tenha sido RUY BARBOSA modesto. O fato é justificável por sua fama, renome, e posição de destaque ocupada no meio jurídico. social e político nas alvôres da primeira República. Um milhão de réis (Rs. 1:000\$000), ou um conto de réis, o valor fixado, representa. va soma vultosa. Sem exagêro talvez equivalha hoje a dez mil cruzeiros novos. Mas não é de estranhar em Ruy tal procedimento. Seus biógrafos relatam em oportunidades repetidas fatos pertinentes aos elevados valôres cobrados por seus trabalhos. Anos mais tarde, em 1905, o Conselheiro Ruy Barbosa como jurisconsulto da Light (The Rio de Janeiro Tramway, Light and Power Company, Limited) recebia Rs. 2:000 $\$ 000$ (dois contos de réis) mensais, apenas por serviços de assessoria e consultas, sem qualquer atividade forense. A carta de nomeação que the foi dirigida pelo presidente da companhia, Alexander Mackenzie, dizia: "Como the expus, não é meu intuito que V. Excia. tenha que acompanhar causas judiciais no fôro, mas que nos seja facultado consultar V. Excia. sôbre todos os interêsses con. cernentes à companhia, e que igual privilégio seja franqueado aos advogados que a representam. Os seus honorários de rs. 2:000\$000 (dois contos de réis) serão satisfeitos no dia 1.0 de cada mês".

De outra feita, em 1904, como advogado do govêrno do Amazonas, na defesa de interêsses dêsse Estado sôbre o Território do Acre, recebeu nada menos do que 300 (trezentos) contos de réis, em parcelas de 30 contos cada uma. Frise-se que Ruy era, então, Senador da República, e por ter advogado interêsses contrários à União foi duramente criticado por seus pares.(1)

Por outro lado, já o Visconde de Ouro Prêto, por parecer idêntico, recebeu a quinta parte daquele valor ou seja, Rs. $200 \$ 000$ (duzentos mil réis), não obstante sua distinguida posição de estadista $e$ jurisconsulto, senador e inclusive presidente do Conselho, quando da queda do Império em 1889.

(1) R. MAGAlHÃES JUNIOR, "Rui ○ Homem e ○ Mito", ed. Civilização Brasileira, Rio, 1964, pg. 248 et passim. 
É evidente que não se pode e não se deve estabelecer qualquer comparação entre os trabalhos pelo simples fato de terem seus auto res recebido valôres tão distintos. Serve apenas como curiosidade.

Passemos ao tema pròpriamente dito.

$$
\text { II - O TEMA DOS PARECERES. }
$$

Vejamos o que nos ensinaram os ilustrados mestres do Direito.

Uma sociedade anônima com matriz no Rio de Janeiro consultou em 1898 os advogados Ruy Barbosa e Affonso Celso de Assis Figueiredo sôbre as seguintes questões:

a) pode uma sociedade anônima reduzir seu capital a determinada quantia, recebendo para isso, em pagamento de débitos de acionistas e pelo valor nominal, as suas próprias ações?

b) a assembléia geral de acionistas, representando mais de dois terços do capital, tinha competência para autorizar a diretoria a tal procedimento?

Essas as duas questões relevantes da consulta.

Como observação preliminar vale notar que, tanto um quanto outro, usaram a expressão "associação anônima", querendo dizer sociedade anônima. Embora não de todo errada, hoje a expressão "associação", jurìdicamente não autoriza a indicação da sociedade anônima, sendo reservada para denominar as sociedades de fins não econômicos, enquanto a sociedade anônima, por fôrça de sua própria lei criadora, tem sempre fim lucrativo e é mercantil qualquer que seja o seu objeto. Na época, contudo, se justificava tal redação, pois a personalidade jurídica das sociedades comerciais era ainda assunto de acirradas controvérsias e obscuro. O Código Comercial de 1850 não afirmou a personalidade jurídica das sociedades comerciais. Apenas do seu conjunto pode deduzir-se tenha o mesmo admitido a personalização das sociedades, e, assim mesmo, de forma pouco nítida. Sòmente em 1916 o Código Civil deu fim à questão.

Com efeito, para o melhor desenvolvimento do tema enfocamos a essência da controvérsia sob dois regimes distintos, o da vigência do Decreto 434, de 4 de julho de 1891, que consolidou as disposições legislativas e regulamentares sôbre as sociedades anônimas, época da elaboração dos documentos sob análise, e o da vigência do Decreto-lei 2.627, de 26.9.1940, até o momento não revogado.

Então vejamos.

(2) J.X. CARVALHO DE MENDONÇA, "Tratado de Direito Comercial Brasileiro", ed. Freitas Bastos, 1963, vol. III, pg. 27/28. 


\section{III - VARIABILIDADE DO CAPITAL.}

O capital é da essência das sociedades comerciais (art. 287 do Código Comercial) e pode ser considerado um "fundo autônomo à disposição dos seus órgãos administrativos para a realização dos fins previstos no ato institucional".(2) Não se confunda capital com patrimônio. Aquêle é espécie e êste gênero.

\section{Em princípio o capiłal é fixo, estabelecido nos estatutos.}

Todavia, o desenvolvimento dos negócios sociais leva normalmente à necessidade da alteração do capital nominal. A valorização dos bens, os lucros apurados, etc., forçam êsse aumento. Em contrapartida, diversos fatôres imprevisíveis podem determinar a redução do capital a um valor inferior determinado. A "redução de capital social é operação pela qual se elimina ou se diminui a diferença entre o capital social e o patrimônio social, ou dêsse se subtrai".(3)

Portanto, ocorrendo um ou outro fenômeno, o capital social pode sofrer alteração. Sua variação, com efeito, para transpor-se ao mundo jurídico, está subordinada a uma alteração estatutária aprovada por assembléia geral.

A alteração estatutária é desnecessária, no entanto, nas chamadas sociedades anônimas de capital autorizado, embora aqui não se trate de alteração do capital fixado nos estatutos, e sim da variação do capital efetivamente realizado. O sistema do capital autorizado, introduzido pela Lei $n .^{\circ} 4.728 / 65$, espelhou-se na tradição inglêsa, que há muito admite a constituição de sociedades com capital subscrito inferior ao autorizado pelo estatuto social.(4) Vale dizer, a sociedade se constitui com um capital de um milhão de cruzeiros, v.g., e apenas a quantia de duzentos mil é subscrita pelos interessados. Posteriormente, por simples decisões da diretoria, o capital efetivamente subscrito pode ser elevado até o autorizado, ou seja, esta elevação de capital em têrmos de realização independe de modificação estatutária.

A variação do capital que ora nos interessa, diz respeito à sua redução. Por isso, analisemos primeiro,

\section{IV - A REDUÇÃO DO CAPITAL NO REGIME DO DECRETO 434/1891.}

O decreto regulamentador das sociedades anônimas, um dos principais documentos editados à primeira hora da bisonha república, silencia sôbre a redução de capital. É evidente, porém, que não

(3) PONTES DE MIRANDA, "Tratado de Direito Privado", ed. Borsoi, 1965, vol. 50, pg. $377, \S 5.330$.

(4) TRAJANO DE MIRANDA VALVERDE, "Sociedades por Ações", ed. Forense, 1959, vol I, pg. 155. 
vedou êsse procedimento, mas, pelo contrário, nas entrelinhas autorizou-o (arts. 91 e 131). Por motivos variados o capital de uma sociedade pode ser reduzido. Mas "não é possível admití-la ou justificá-la com ofensa dos dois princípios fundamentais: a igualdade entre os acionistas e os direitos adquiridos de terceiros".(5)

J.X. CARVALHO DE MENDONÇA aponta três sistemas adotados para a redução do capital de sociedade anônima: a) - a redução uniforme do valor nominal de cada ação; b) - a diminuição proporcional ao número das ações sem redução do seu valor nominal; c) - resgate das ações; (êste sistema, diz o consagrado comercialista, "encontra embaraços em nossa lei, que não permite às sociedades anônimas comprar as próprias ações, salvo para amortização destas. que é coisa muito diversa da redução do capital. É, conseqüentemente, um processo condenado, porque não sòmente a sociedade pode entrar em operações especulativas das próprias ações, como pode operar o reembôlso do capital sob a capa da sua redução".(6)

Pois bem, o objetivo da consulta e respectivos pareceres analisam especificamente êste último sistema, concluindo Ruy Barbosa por sua absoluta validade e o Visconde de Ouro Prêto por sua condenação.

Ruy sustentou que as assembléias gerais extraordinárias especìficamente convocadas têm competência para modificar o capital, onde, ipso facto, se inclui o critério da escolha dos meios para êsse fim. Para a consecução dêsse fim legal é preciso, assevera, que não se utilizem meios ilegais. Desenvolvendo seu ponto de vista, viu na proibição do art. 40 do Regulamento 434, um meio de impedir as sociedades anônimas de realizar negócios com suas próprias ações, coibindo assim as operações fictícias e de mera especulação. A proibição de comprar e vender, entendeu, está na lei no sentido limitado de impedir êsse tipo de negócio.

Os motivos do vêdo constante do artigo 40 são bem definidos por SALVADOR MONIZ, quando diz: "Dois são os motivos pelos quais o nosso Direito assim determinou, a saber: impedir que as sociedades anônimas, por tais operações, promovam a alta e a baixa fictícia de suas próprias ações; evitar que as referidas sociedades anônimas, simulando a compra, paguem na realidade aos acionistas a importâncias das ações, violando o princípio de que os acionistas não podem ser pagos do valor de suas ações".(7)

Este é o sentido próprio e restrito da lei. Seu objetivo único. segundo o autor do parecer.

(5) J.X. CARVALHO DE MENDONÇA, idem, pág. 403.

(6) Idem, pg. 403/405.

(7) SALVADOR MONIZ, "Sociedades Anônimas", ed. Francisco Alves e Cia. 1919, pág. 194. 
O próprio dispositivo citado, no entanto, abre exceção, quando permite a amortização das ações, desde que realizada com fundos disponíveis e sem ofensa do capital. Mostrando que o Código Comercial alemão, o húngaro e o Código Suíço de Obrigações, proíbem à sociedade comprar as suas próprias ações, mas permitem quando se trata de reduzir o capital, observadas as exigências de lei, conclui por afirmar que a operação de que se trata longe está de incorrer na vedação do art. 40 do decreto 434 , cabendo, a seu ver, claramente na permissão do mesmo artigo.

Entendeu Ruy tratar-se a operação de uma espécie de amortização, admitida pela lei, já que realizada sem desfalque do capital e com recursos disponíveis. (Os débitos dos acionistas). A operação objeto da consulta não estaria, assim, enquadrada na proibição do art. 40 porque não era seu propósito a especulação das ações, mas uma simples redução do capital com a retirada de circulação das ações recebidas em pagamento de débitos de acionistas.

Outrossim, concluiu que a assembléia geral de acionistas tinha competência para autorizar à diretoria receber as ações - e reduzir o capital.

\section{IV-A - A POSIÇÃO DE RUY}

A conclusão a que chegou representava na época ponto de vista quais 0 nosso Direito assim determinou, a saber: impedir que as LAFAYETTE RODRIGUES PEREIRA, em pareceres datados de 1893. endossaram a sua tese.(8)

LAFAYETTE, o consagrado autor do "Direito das Coisas" e outras obras reveladoras de sua notável sabedoria jurídica, adotou conclusão idêntica à de Ruy. Mais pròpriamente, Ruy foi quem, ao manifestar-se sôbre o assunto, adotou posição similar a LAFAYETTE. pois os pareceres são de 1898 e 1893 respectivamente.

Os fundamentos do ponto de vista convergente são os mesmos. Vale anotá-los: a possibilidade de redução do capital pela compra de ações com fundos disponíveis (os débitos dos acionistas), a que chamam de amortização; e o entendimento de que $\circ$ art. 40 do decr. 434 não proíbe a compra de ações nas condições acima, mas veda a negociação de ações com fins especulativos.

Como se verá mais adiante, porém, o uso da fórmula amortiza. ção para validar a operação é indevido e totalmente impróprio.

Para se avaliar até onde se ajustam as opiniões dos autores em

(8) Revista "O DIREITO", Rio de Janeiro, 1895, vol. 67, pg. 15 e 19. 
referência, é de se transcrever parte do parecer de LAFAYETTE: "A sociedade anônima pode reduzir o seu capital. Não há disposição da lei que o proíba, expressa ou tàcitamente. E a redução, como é óbvio, não se pode fazer, senão adquirindo a mesma sociedade, por compra ou outro qualquer título, as próprias ações até a concorrente soma da quantia em que se pretende diminuir o capital, e amortizando-se. A amortização é admissível desde que há fundos disponíveis para isso. Portanto, é fora de dúvida que a assembléia geral, observados os requisitos que se exigem para a reforma dos estatutos, pode legalmente tomar a deliberação a que alude êste quesito". (destacamos) (8a)

Porém, contrariando suas posições havia a própria lei e o pêso da sabedoria e clarividência de J.X. CARVALHO DE MENDONÇA, SOUZA RIBEIRO, FERREIRA VIANA, CARLOS DE CARVALHO, ULYSSES VIANNA e VISCONDE DE OURO PRÊTO, além de outros nomes de menor expressão.(9)

$\mathrm{Na}$ verdade, à época da consulta, era inadmissível tal operação. As sociedades anônimas estavam impedidas de adquirir as próprias ações, em razão dos motivos acima alegados. O artigo 40 do decreto 434 não deixa margem a dúvidas. A prática dêsse ato, inclusive, sujeitava os administradores à pena de prisão celular de um a quatro anos, conforme o disposto no artigo 201 do citado decreto. E o ato era nulo.

Pretender com Ruy que o negócio era uma forma de amortiza ção, significa subverter o conceito dessa figura jurídica. A amortiza. ção é operação bem diversa da redução de capital. Ê de CARVALHO DE MENDONÇA a expressão "amortizar as ações não quer dizer reduzir o capital; evite-se a confusão a êsse respeito".

Ademais, a forma preconizada para a operação, de dação in solutum, equivale a compra e venda, e como tal, condenada. A datio in solutum é forma de extinção de obrigação que se equipara à compra e venda e rege-se pelas regras pertinentes a ela. Para melhor eluci dação, vejamos algumas opiniões a respeito. ULYSSES VIANNA assevera:

"Facultar e receber em pagamento de dívidas as próprias ações, o que importaria em uma dação in solułum, seria negociar com elas ou sôbre elas, o que a lei proíbe, e importaria em reduzir o capital social (sem ser pela forma que a lei autoriza), e conseqüentemente as garantias dos credores. Lyon Caen \& Renault - Traité des Sociétés Com.

(8a) Revista "O DIREITO", Rio de Janeiro, 1895, vol. 67 p. 19.

(9) Revista "O DIREITO", Rio de Janeiro, 1895, vol. 67, pg. 15/23. 
merciales n. 880, que cita sôbre a matéria vários julgados dos tribunais franceses".

SOUZA RIBEIRO ensina:

"O pagamento de dívidas com ações importaria dação in solutum, regida pelos princípios da compra e venda; e as sociedades não podem comprar suas próprias ações, senão amortizá-las com fundos disponíveis, sem ofensa do capital (Decreto citado art. 40 e 201 n. ' 1)".

CARLOS DE CARVALHO observa:

"Assim respondo: Ao $1 .^{\circ}$ quesito: a assembléia constituída pela forma indicada no $\S 4$ do art. 15 do decreto n. 164 de 17 de janeiro de 1890 pode por maioria de votos decretar a redução do capital; não poderá, porém, dispor que essa redução se verifique por meio de aquisição de suas próprias ações por compra, troca ou dação in solu. fum. A aquisição de ações só é lícita para amortizá-las. sem ofensa de capital, o que é justamente o oposto da deliberação de reduzi-lo".

E finalmente o VISCONDE DE OURO PRÊTO, em pa. recer diverso do ora publicado, categòricamente afirma: "É lícito a assembléia geral autorizar a diretoria a rece. ber em pagamento as próprias ações da respectiva com. panhia?

Não; a dação in solutum equivale à compra e venda e às associações anônimas é vedada a compra de suas ações, salvo para amortizá-las e contanto que a compra se faça com fundos disponíveis".(10)

Vê-se assim que Ruy Barbosa deu interpretação própria e sui generis ao vêdo legal, para concluir favoràvelmente aos interêsses de seu cliente. Mas, honestamente, não acreditamos tivesse razão. Tanto que dois Bancos da Capital da República, para reduzir seu capital, recebendo as próprias ações em pagamento de dividas, tiveram autorização legislativa para assim proceder, o que vem confirmar a regra da invalidade do procedimento na esfera estrita da administração da sociedade anônima. Em 1892, através do Decreto n. ${ }^{\circ} 1.167$, - Banco da República foi autorizado a reduzir o seu capital na forma pretendida e no ano seguinte, pelo Decreto $n .^{\circ} 1.361$ ○ Banco Hypotecário do Brasil recebeu igual autorização. Não nos parece que tais precedentes legislativos tenham o condão de confirmar a tese de Ruy, mas, pelo contrário, demonstram a invalidade da operação,

(10) Idem, ibidem. 
reconhecida como ato jurídico perfeito sòmente com o batismo legislativo. É evidente que, admitida normalmente a prática da operação, despicienda seria a autorização legal.

\section{IV-B - A POSIÇÃO DO VISC. DE OURO PRETTO.}

Mais feliz em sua conclusão foi o Visconde de Ouro Prêto. Com a lei e a melhor doutrina, sustentou a ilegalidade de tal processo de redução do capital e foi mais além, viu alí uma forma de fraude e de crime (art. 201 do decr. 434).

A redução, como pretendida pela consulente, era impossível, porque não autorizada em lei. Esta proibia que a sociedade comprasse suas ações. Ora, equiparando-se a dação in solutum à compra e venda, incidia na proibição legal. Enfim, como assegura S. VAMPRÉ: "Também se proíbe à sociedade anônima adquirir as próprias ações por troca ou dação em pagamento".(11)

A própria lei, como já se frisou, abria uma exceção. A sociedade anônima podia comprar as suas ações para amortizá-las, tirá-las de circulação, mas desde que o fizesse com fundos disponíveis e sem ofensa do capital. Todavia, o consulente se propunha realizar uma espécie de amortização com redução do capital, o que era vedado. A amortização é um adiantamento que se efetua em dinheiro aos acionistas por conta da restituição do capital e lucros, que se devem distribuir por ocasião da liqüidação da sociedade, porém exige que o capital se mantenha, real e nominalmente, o mesmo.

No caso sob análise ocorria exatamente o inverso: o capital se reduzia com a aquisição das ações.

Assim sendo, pode-se afirmar que para a época o parecer de Ouro Prêto revelava uma posição doutrinária coerente e lógica. Mais do que isto, era consentânea aos princípios legais vigentes.

\section{V - A REDUÇÃO DO CAPITAL NO REGIME DO DECRETO-LEI $2.627 / 1940$.}

O nôvo estatuto das sociedades anônimas grandes alterações trouxe em relação ao diploma revogado. Adaptou a matéria ao regime político inaugurado em novembro de 1937. Tornou-se compatível com êle. Respeitou os princípios da "Ordem Econômica" da Constituição e fortaleceu a instituição jurídica, facilitando, assim, o desenvolvimento da economia nacional.(12)

(11) S. VAMPRE, "Tratado Elementar de Direito Comercial", ed. F. Briguet e Cia., Rio, 1922, vol. II, pág. 163.

(12) TRAJANO DE MIRANDA VALVERDE, "Justificação do Anteprojeto da Lei de Sociedades por Ações", Rio, 1939. 
O nôvo estatuto não silenciou sôbre a redução de capital, como fêz o anterior. Trouxe normas expressas que deram novos contornos à espécie, além de tratá-la objetivamente.

Assim é que a redução nos têrmos da lei, pode ser coativa (determinada por lei) ou voluntária (em razão de deliberação da assembléia geral).

São casos de redução compulsória os previstos nos artigos 77 e 107 do citado decreto-lei. A primeira hipótese ocorre quando as ações não integralizadas, de acionistas em mora, não encontram comprador no prazo de um ano, ocasião em que a assembléia geral será convocada para tomar conhecimento da redução do capital. A outra se verifica quando não forem substituídos, no prazo d 90 dias, a contar da publicação da ata da assembléia, os acionistas cujas ações tenham sido reembolsadas em razão de dissidência à aprovação das matérias previstas nas letras a, d, e, e g, do art. 105.

A redução voluntária, por sua vez, é regulada pelos artigos 114 e 115, do diploma em espécie, e pode decorrer dos mais variados fatôres, tais como verificação de prejuízos, excesso de capital, etc... Também o resgate de ações, previsto no artigo 16 do decreto-lei em questão, é razão de redução voluntária do capital.

O nôvo estatuto trouxe igualmente proibição da sociedade anônima de comprar e vender suas ações, mas de forma mais ampla. $O$ art. 15 dispõe que a sociedade anônima não pode negociar com as próprias ações. O dispositivo, sem dúvida, com a nova redação, é bem mais genérico que o seu equivalente do dec. 434. A expressão negociar, na verdade, parece mais apropriada para os fins a que se propõe, em relação à indicação singular do contrato de compra e venda.

A grande inovação do decreto-lei do Estado Nôvo, porém, foi a autorização concedida pelo artigo 19 às sociedades anônimas de comprar suas ações desde que reduzido o capital e restituído em dinheiro o seu valor, sendo o preço destas emBôlsa inferior ou igual à importância que deva ser restituída. As ações assim adquiridas são retiradas de circulação.

$\mathrm{O}$ dispositivo veio ajustar uma situação de fato irregular. $\mathrm{Na}$ verdade, operações dessa natureza se realizavam sem a necessária cobertura legal. Até então a solução era controvertida. Aí estão os pareceres a confirmar a existência da polêmica.

Autorizando as sociedades a comprar suas ações, com a necessária redução de capital, a norma legal ora vigente pôs por terra tôda 
a discussão sôbre o assunto. Duas conclusões imediatas se podem extrair daí:

a) - A partir da vigência do decreto-lei é absolutamente válida a redução do capital da sociedade anônima com o recebimento de ações em pagamento de débitos de acionistas, pois, como já se frisou, a dação in solutum equivale à compra e venda e como tal, está autorizada pela regra analisada, quando decidida a redução do capital;

b) - a proibição de negociar com suas ações se propõe agora, objetivamente, a impedir que as sociedades especulem com suas ações, provocando altas ou baixas fictícias.

$$
\text { VI - CONCLUSÃO }
$$

O tempo cuidou de dar razão a Ruy. Antecipando-se quarenta anos à lei, via êle na operação pretendida uma forma justa e razoável de atender a uma situação anormal e momentânea da sociedade anônima. Enxergava o futuro com dados da época. Seu ponto de vista, afinal, foi vencedor. O mérito do seu trabalho está exatamente nesse particular. Na agudeza da análise do texto legal. Na perspicácia da observação dos fatos.

E êsse mérito jamais poderá ser contestado, porque "os grandes cérebros sobem ùnicamente pelo caminho do mérito ou por nenhum".(13) 